\title{
EVALUATION OF HYDROLOGICALLY RELEVANT PCM CLIMATE VARIABLES AND LARGE-SCALE VARIABILITY OVER THE CONTINENTAL U.S.
}

\author{
CHUNMEI ZHU ${ }^{1}$, DAVID W. PIERCE ${ }^{2}$, TIM P. BARNETT ${ }^{2}$, ANDREW W. WOOD ${ }^{1}$ \\ and DENNIS P. LETTENMAIER ${ }^{1 \star}$ \\ ${ }^{1}$ Department of Civil and Environmental Engineering, University of Washington, \\ Seattle, WA 98195, U.S.A. \\ E-mail: dennisl.@u.washington.edu \\ ${ }^{2}$ Climate Research Division, Scripps Institution of Oceanography, University of California, \\ San Diego, La Jolla, CA 92093, U.S.A.
}

\begin{abstract}
The ability of the Parallel Climate Model (PCM) to reproduce the mean and variability of hydrologically relevant climate variables was evaluated by comparing PCM historical climate runs with observations over temporal scales from sub-daily to annual. The domain was the continental U.S, and the model spatial resolution was T42 (about 2.8 degrees latitude by longitude). The climate variables evaluated include precipitation, surface air temperature, net surface solar radiation, soil moisture, and snow water equivalent. The results show that PCM has a winter dry bias in the Pacific Northwest and a summer wet bias in the central plains. The diurnal precipitation variation in summer is much stronger than observed, with an afternoon maximum in summer precipitation over much of the U.S. interior, in contrast with an observed nocturnal maximum in parts of the interior. PCM has a cold bias in annual mean temperature over most of the U.S., with deviations as large as $-8 \mathrm{~K}$. The PCM daily temperature range is lower than observed, especially in the central U.S. PCM generally overestimates the net solar radiation over most of the U.S, although the diurnal cycle is simulated well in spring, summer and winter. In autumn PCM has a pronounced noontime peak in solar radiation that differs by $5-10 \%$ from observations. PCM's simulated soil moisture is less variable than that of a sophisticated land-surface hydrology model, especially in the interior of the country. PCM simulates the wetter conditions over the southeastern U.S. and California during warm (El Niño) events, but shifts the drier conditions in the Pacific Northwest northward and underestimates their magnitude. The temperature response to the North Pacific Oscillation is generally captured by PCM, but the amplitude of this response is overestimated by a factor of about two.
\end{abstract}

\section{Introduction}

Water is an important and limited resource in the western United States. It is used in agriculture, hydroelectric power generation, and industrial and domestic applications. Because of the limited supply and wide ranging uses, any changes to the future water supply in the region would be of great practical importance and have significant economic consequences.

$\star$ Corresponding author. 
The accelerated climate prediction initiative (ACPI) chose as its demonstration project an 'end-to-end' prediction of the consequences of climate variability and change on the hydrology and water supplies of the western U.S. over the next century. Accurate climate forecasts can have significant economic benefits. For example, California suffered $\$ 1.1$ billion weather-related losses during the 1997/98 El Niño episode, and \$2 billion during the 1982/83 event of similar magnitude. The difference was likely the widespread media coverage of predictions for the 1997 event, which allowed people time to prepare (Changnon, 1999).

The ACPI project was composed of three elements: (1) initializing a coupled global climate model with conditions observed in the late 20th century; (2) integrating the model forward to the decade of the 2050s using projected anthropogenic forcing $\left(\mathrm{CO}_{2}\right.$ and sulfates); (3) downscaling the global model results to determine regional impacts on the hydrological cycle. The project is described more fully in Barnett et al. 2004 (this issue) and the works referenced therein.

The coupled ocean-atmosphere general circulation model (O-A GCM) chosen for the first two elements of the project was the parallel climate model (PCM; Washington et al., 2000), version one. The atmospheric component of PCM is CCM3, the Community Climate Model version 3 (Kiehl et al., 1998), which was run at T42 resolution (approximately $2.8^{\circ}$ latitude by longitude) and 18 vertical levels. The ocean component is POP, the Parallel Ocean Program (Smith et al., 1992; Dukowicz and Smith, 1994) run at 388 by 280 grid point resolution (approximately $2 / 3^{\circ}$ ) with 32 vertical levels. The sea ice component is a dynamic-thermodynamic model (based on Zhang and Hibler, 1997) with an elastic-viscous-plastic rheology (Hunke and Dukowicz, 1997), run on two separate grids of 320 by 320 points, one covering each polar region. The National Center for Atmospheric Research Land Surface Model (LSM version 1.0) provides a comprehensive treatment of land surface processes for the CCM3 (Bonan, 1998). The LSM land model which replaces the prescribed surface wetness and snow cover used in CCM2, allows for land-atmosphere interactions, although in the version used in this study vegetation characteristics such as leaf area index had a prescribed annual cycle. Further details of the models and runs are given in Dai et al. (2004, in this issue).

Because the focus of the ACPI demonstration project was the hydrology and water resources of the western U.S., it is important to evaluate how PCM's simulations of relevant climate variables over that region compare to observations. In addition, interannual to decadal timescale climate variability over the western U.S. is known to be influenced by large-scale phenomena such as the El NinoSouthern Oscillation (ENSO; see e.g., Ropelewski and Halpert, 1986; Cayan and Webb, 1992) and the North Pacific Oscillation (NPO; Latif and Barnett, 1996; also known as the Pacific Decadal Oscillation or PDO, Mantua et al., 1997).

A complete picture of PCM's simulation of climate over the continental U.S. in the context of ACPI needs to include an overview of the model's ability to reproduce hydrologically important surface variables, as well as measures of large-scale variability, such as ENSO and NPO/PDO. The purpose of this paper is to sumarize 
such an evaluation of PCM, focusing on factors that influence hydrology and water resources. Although our primary focus is on the western U.S., for many variables it is instructive to provide a wider perspective of model performance. Therefore, our analysis domain is the entire continental U.S., but in light of ACPI's focus on the western U.S., we give particular attention to the area west of the continental Divide. The surface variables investigated are precipitation, temperature, soil moisture, solar radiation; and snow water equivalent, as well as the teleconnected expression of some of these variables due to remote forcing. In the western U.S., precipitation is a limiting variable in many respects, and snow pack acts as an important natural reservoir in the hydrological cycle that retains winter precipitation through the wet season and later releases it during the dry summer months. Therefore we investigate the details of the seasonal temperature and solar radiation cycle, which strongly affect the snow regime, in addition to precipitation and snow water equivalent accumulations.

The remainder of this paper is organized as follows. Section 2 describes the data sets and data processing methods used. Section 3 presents the results, including comparisons of the relevant climate variables with observations over the continental U.S., and an evaluation of large-scale teleconnections that affect the region. Section 4 is devoted to interpretation of results and conclusions.

\section{Approach}

The primary source of evaluation data was the retrospective Land Data Assimilation System (LDAS) data set of Maurer et al. (2002). The Maurer et al. data are of three types. The first are gridded climatalogical (daily) observations of precipitation and maximum and minimum daily temperature, taken from some 12,000 National Climatic Data Service (NCDC) cooperative observer stations over the continental U.S. for the period 1950 through mid-2000. These data were gridded using the SYMAP algorithm of Shepherd et al. (1984) as described in Maurer et al. (2002), to the $1 / 8$ degree latitude by longitude LDAS grid. For precipitation, the long-term means of the gridded data were adjusted to match the PRISM (Parameter-elevation Regressions on Independent Slopes Model) of Daly et al. (1994), and temperatures were lapsed to the grid cell mean elevation. This step is important for evaluation of precipitation (and surface air temperature) over the western U.S., as these variables are strongly affected by orography.

The second type of data is surface radiative fluxes (downward solar and longwave radiation) and meteorological variables (e.g., humidity), which were derived using published algorithms (Kimball et al., 1997, Thornton and Running, 1999) based on daily temperature maxima and minima, and/or precipitation. The third type of data are hydrological state variables (soil moisture, snow water equivalent, and soil temperature) and fluxes (latent, sensible, and ground heat flux; and upward solar and longwave radiation) derived using the first two classes of variables to 
drive the Variable Infiltration Capacity (VIC) land surface model (Liang et al., 1994). VIC is a macroscale hydrology model designed both for off-line, or standalone use to simulate the water and energy budgets of large areas (e.g., large continental river basins, or continents), and for use in coupled land-atmosphere models to simulate the role of the land surface in partitioning moisture and energy. As compared with other land surface models, it is distinguished by its focus on land surface hydrological processes, especially runoff generation. Maurer et al. (2002), as well as various papers reporting on applications to continental U.S. river basins (e.g., Abdulla et al., 1996; Nijssen et al., 1997; Payne et al. (2004, this issue; VanRheenen et al., 2004, this issue) and global river basins (Nijssen et al., 2001) have demonstrated the ability of the model to reproduce land surface hydrologic state variables (soil moisture, snow) and fluxes (streamflow, evapotranspiration) over large areas. In addition to the retrospective LDAS data reported in Maurer et al. (2002), we make use of a set of hourly index precipitation stations across the continental U.S. These stations were picked for completeness of records and geographic representativeness, and were the basis for our evaluation of the diurnal cycle of simulated PCM precipitation reported in Section 3.1. Details of these data are available from http://www.hydro.washington.edu/Lettenmaier/Models/VIC/Operation/p_disag.html. Subdaily 3-hourly temperatures were interpolated by fitting an asymmetric spline through the daily maximum and minima (Maurer et al., 2002).

Monthly model output fields evaluated were from PCM run B06.22 (Washington et al., 2000), which is an historical run based on observed global atmospheric emissions for the period 1950-1999. We also used hourly output data from a second PCM run (B06.64), for a shorter historical period 1995-1999. This model run is described at http://www-pcmdi.llnl.gov/modeldata/PCM_Data/pcgdahome. html. PCM atmospheric data is at the spatial resolution of 2.8 degrees. In order to compare PCM output to gridded observations and VIC output at a common spatial resolution, all of the monthly, daily and hourly data at the 1/8 degree LDAS resolution of Maurer et al. (2002) were aggregated to the PCM grid scale before comparison. For comparisons of the simulated diurnal cycle of selected variables, PCM hourly output was first aggregated and then averaged over 3-hour time steps. All of the annual and seasonal spatial pattern comparisons reported in Section 3 used 50-year averages (1950-1999) of the Maurer et al. data. In addition to precipitation means, we report a comparison of storm inter-arrival times, defined as the time from the end of one sequence of uninterrupted precipitation to the beginning of another. For this purpose, we used a $2.5 \mathrm{~mm} /$ day threshold to define 'wet' versus 'dry' days. For comparisons of soil moisture, we used the PCM variable RSW, which is the root zone soil moisture to a depth 0.7 meter. The soil moisture from the top 0.7 meter from the VIC model is used for comparison with RSW.

For examining the large-scale teleconnection patterns of ENSO and the NPO (Sections 3.5 and 3.6) we used the da Silva (1995) data sets. These are globally gridded, ocean-only, quality-controlled products based on the COADS data. Horizontal resolution is 1 degree in latitude and longitude, with monthly tem- 
poral resolution. Table I lists all variables used in this paper. Also listed are the data source, PCM variable names, and VIC derived variables corresponding to the Maurer et al. (2002) data.

\section{Results and Discussion}

\subsection{PRECIPITATION}

Annual and Seasonal Spatial Patterns of Means: The annual and seasonal spatial distributions of observed and PCM-simulated precipitation, and their differences, are shown in Figure 1. On an annual basis, PCM tends to underestimate precipitation in the Pacific Northwest and the Southeast, and overestimate it in the Midwest and Great Plains. The highest annual precipitation differences are about $1000 \mathrm{~mm}$ in the Pacific Northwest, in parts of the mountainous West, and in some parts of the Southeast such as Mississippi and Louisiana. Differences generally are smaller (maximum differences are about $200 \mathrm{~mm}$ ) in the spring and autumn transition seasons. Most (over half) of the annual precipitation difference (about $500 \mathrm{~mm}$ ) in the Pacific Northwest is associated with the winter season. In the Midwest and Great Plains, most of the overestimate $(\sim 700 \mathrm{~mm})$ occurs in summer. On the other hand, in the Southeast the difference is relatively uniformly distributed over the four seasons. In the central part of the country, the summer overestimation is associated with unrealistically strong convective precipitation, as is the negative bias in the Southeast (http://ecpc.ucsd.edu/projects/acpi/pre_taiwan/Summary.html). The summer overestimate in the Great Plains and high mountain areas associated with excess convective activity is known to be caused by orographic locking of precipitation in the model (Bonnan, 1996), and is attributable to PCM model physics such as the deep cumulus parameterization of Zhang and McFarlane (1995).

Daily Storm Statistics: The sequencing of precipitation events is important because of the role precipitation timing plays in runoff generation. Runoff generation is a highly nonlinear process that is sensitive not only to the total amount of precipitation, but to its intermittency and variability. For this analysis, 'storms' were defined as being sequences of days for which total precipitation exceeded a given threshold ( $2.5 \mathrm{~mm} /$ day). Figures $2 \mathrm{a}, \mathrm{c}$ compare summer and winter empirical probability distributions of observed and PCM storm inter-arrivals, that is, the time in days from the beginning of one storm to the next. The figures show that in summer PCM performs well in the coastal areas of the East, and in the Northern Great Plains, but tends to overestimate storm inter-arrival times in the Southeast and the coastal areas of the West. Storms in PCM occur more frequently than observed in the central U.S., which is probably associated with the weak onset criteria of CCM3 moist convection process (Dai, 1999a). In winter, the differences between the PCM-simulated storms and observations are modest in the Southeast, in the coastal area of the East, and in the West. In the Northern Great Plains and the central U.S., the model severely underestimates winter storm inter-arrival periods. 
Table I

Variables and data source from PCM, observation and VIC output

\begin{tabular}{|c|c|c|c|c|c|}
\hline Variable & Plot & $\begin{array}{l}\text { Actual variable } \\
\text { name in } \mathrm{PCM}\end{array}$ & PCM data & Observations & $\begin{array}{l}\text { Variable reference in } \\
\text { LDAS data (Maurer } \\
\text { et al., 2002) }\end{array}$ \\
\hline \multirow[t]{3}{*}{ Precipitation } & $\begin{array}{l}\text { Annual and } \\
\text { seasonal } \\
\text { comparison } \\
\text { (Figure 1) }\end{array}$ & \multirow[t]{3}{*}{$\begin{array}{l}\text { PRECC } \\
\text { PRECL }\end{array}$} & $\begin{array}{l}\text { PCM B06.22 } \\
\text { (monthly data, } \\
1950-1999)\end{array}$ & $\begin{array}{l}\text { Gridded monthly } \\
\text { forcing }\end{array}$ & Monthly precipitation \\
\hline & $\begin{array}{l}\text { Daily } \\
\text { statistics } \\
\text { (Figure 2) }\end{array}$ & & $\begin{array}{l}\text { PCM B06.22 } \\
\text { (daily data, } \\
\text { 1950-1999) }\end{array}$ & $\begin{array}{l}\text { Gridded daily } \\
\text { forcing }\end{array}$ & Daily precipitation \\
\hline & $\begin{array}{l}\text { Mean } \\
\text { diurnal cycle } \\
\text { (Figure 3) }\end{array}$ & & $\begin{array}{l}\text { PCM B06.64 } \\
\text { (hourly data, } \\
\text { 1995-1999) }\end{array}$ & $\begin{array}{l}\text { LDAS gridded } \\
\text { VIC output } \\
\text { (3-hourly, 1995- } \\
\text { 1999) }\end{array}$ & 3-hourly precipitation \\
\hline \multirow[t]{2}{*}{ Temperature } & $\begin{array}{l}\text { Annual and } \\
\text { seasonal } \\
\text { comparison } \\
\text { (Figure 4) }\end{array}$ & \multirow[t]{2}{*}{ TREFHT } & $\begin{array}{l}\text { PCM B06.22 } \\
\text { (monthly data, } \\
1950-1999)\end{array}$ & $\begin{array}{l}\text { LDAS gridded } \\
\text { VIC output } \\
\text { (monthly, 1950- } \\
\text { 1999) }\end{array}$ & $\begin{array}{l}\text { 2-Meter Air } \\
\text { Temperature }\end{array}$ \\
\hline & $\begin{array}{l}\text { Mean } \\
\text { diurnal cycle } \\
\text { (Figure 5) }\end{array}$ & & $\begin{array}{l}\text { PCM B06.64 } \\
(1995-1999)\end{array}$ & $\begin{array}{l}\text { LDAS gridded } \\
\text { VIC output } \\
\text { (3-hourly, 1995- } \\
\text { 1999) }\end{array}$ & \\
\hline \multirow[t]{2}{*}{$\begin{array}{l}\text { Net solar } \\
\text { radiation on } \\
\text { surface } \\
\text { (downward) }\end{array}$} & $\begin{array}{l}\text { Annual and } \\
\text { seasonal } \\
\text { comparison } \\
\text { (Figure 6) }\end{array}$ & \multirow[t]{2}{*}{ FSNS } & $\begin{array}{l}\text { PCM B06.22 } \\
\text { (monthly data, } \\
50 \text { years) }\end{array}$ & $\begin{array}{l}\text { LDAS gridded } \\
\text { VIC output } \\
\text { (monthly, 1950- } \\
\text { 1999) }\end{array}$ & \multirow[t]{2}{*}{ Net shortwave } \\
\hline & $\begin{array}{l}\text { Mean } \\
\text { diurnal cycle } \\
\text { (Figure 7) }\end{array}$ & & $\begin{array}{l}\text { PCM B06.64 } \\
(1995-1999)\end{array}$ & $\begin{array}{l}\text { LDAS gridded } \\
\text { VIC output } \\
\text { (3-hourly, 1995- } \\
\text { 1999) }\end{array}$ & \\
\hline Soil moisture & $\begin{array}{l}\text { Annual and } \\
\text { seasonal } \\
\text { range } \\
\text { comparison } \\
\text { (Figure 8) }\end{array}$ & RSW & $\begin{array}{l}\text { PCM B06.22 } \\
\text { (monthly data, } \\
50 \text { years) }\end{array}$ & $\begin{array}{l}\text { LDAS gridded } \\
\text { VIC output } \\
\text { (monthly) }\end{array}$ & $\begin{array}{l}\text { Soil Moisture Layer } \\
1 \text {, Layer } 2 \text { and Layer } \\
3\end{array}$ \\
\hline
\end{tabular}




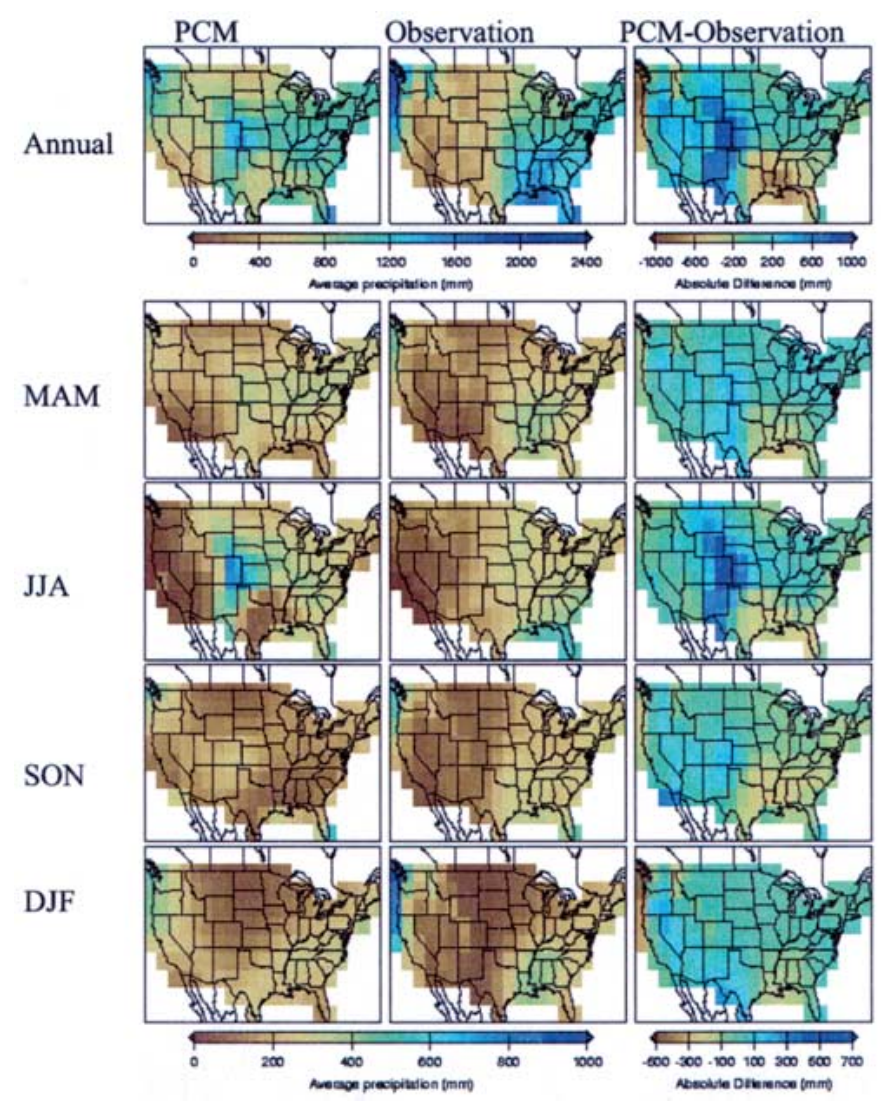

Figure 1. Mean annual and seasonal precipitation for PCM and gridded observations, 1950-1999.

Figures $2 \mathrm{~b}$,d show modeled and observed summer and winter storm durations. In summer, over most of the continental U.S., PCM-simulated storms have much longer durations than observed. This is particularly true in the central U.S., where PCM storms can last 30 days, while observed storm durations are almost all less than 15 days. In winter, PCM performs much better. Although the differences between PCM and observations are not large, PCM does tend to underestimate storm durations in the eastern half of the country and in the Northwest, and overestimate them in the central U.S. and the Southwest. The most unrealistically short storms are found in the Pacific Northwest. In coastal areas of Washington and Oregon, observed storm durations can exceed 24 days, whereas the longest PCM storm durations are 12 days. This may be the cause for the severe winter precipitation dry bias in Pacific Northwest. Overall, PCM tends to give storms with lower frequency in summer and shorter duration in winter than observed in the Pacific Northwest, and higher frequency and longer storm duration in summer and higher frequency in winter in the central U.S. 
A.

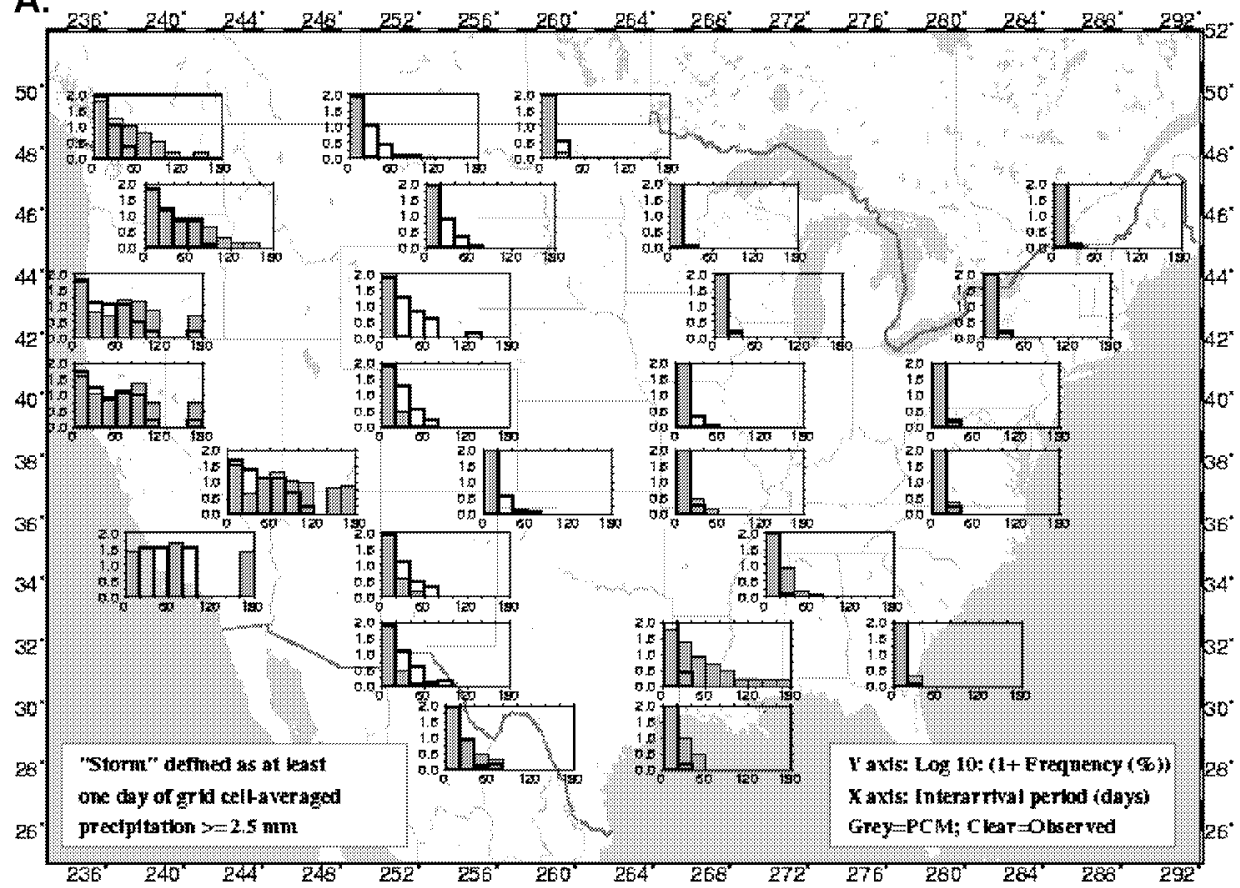

B.

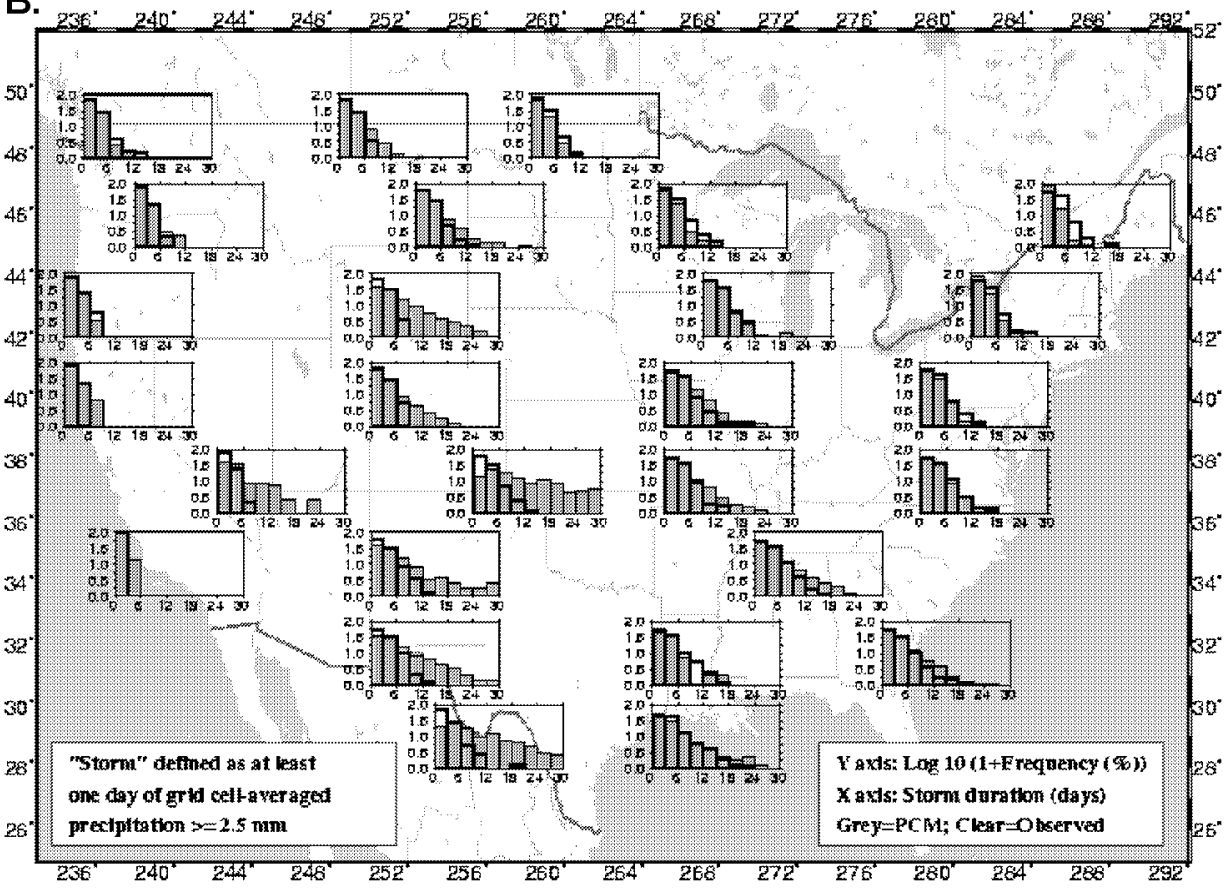

Figures 2a,b. Daily storm statistic distributions for PCM and observations, 1950-1999: (a) Summer (JJA) storm interarrival distribution, (b) Summer (JJA) storm duration distribution. 
C.

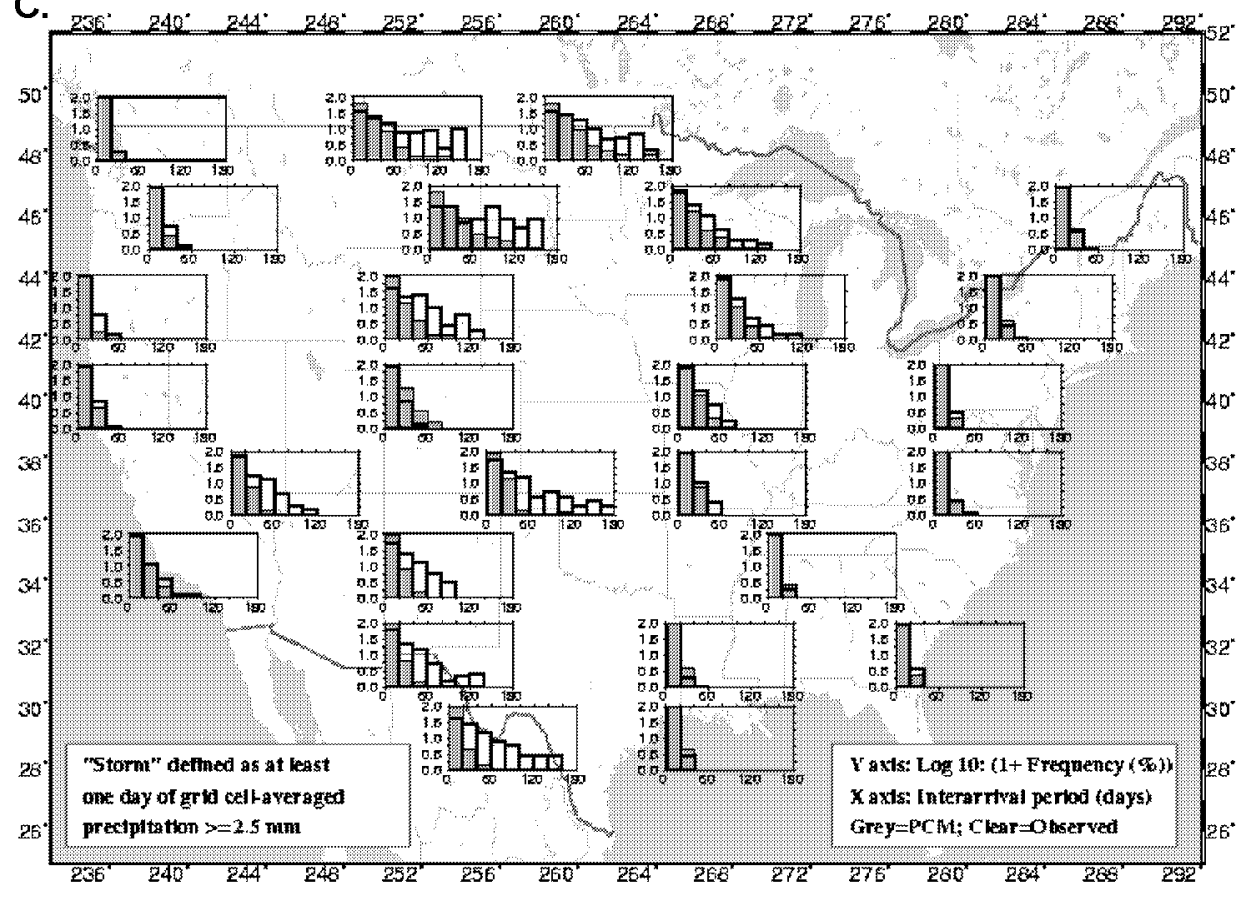

D.

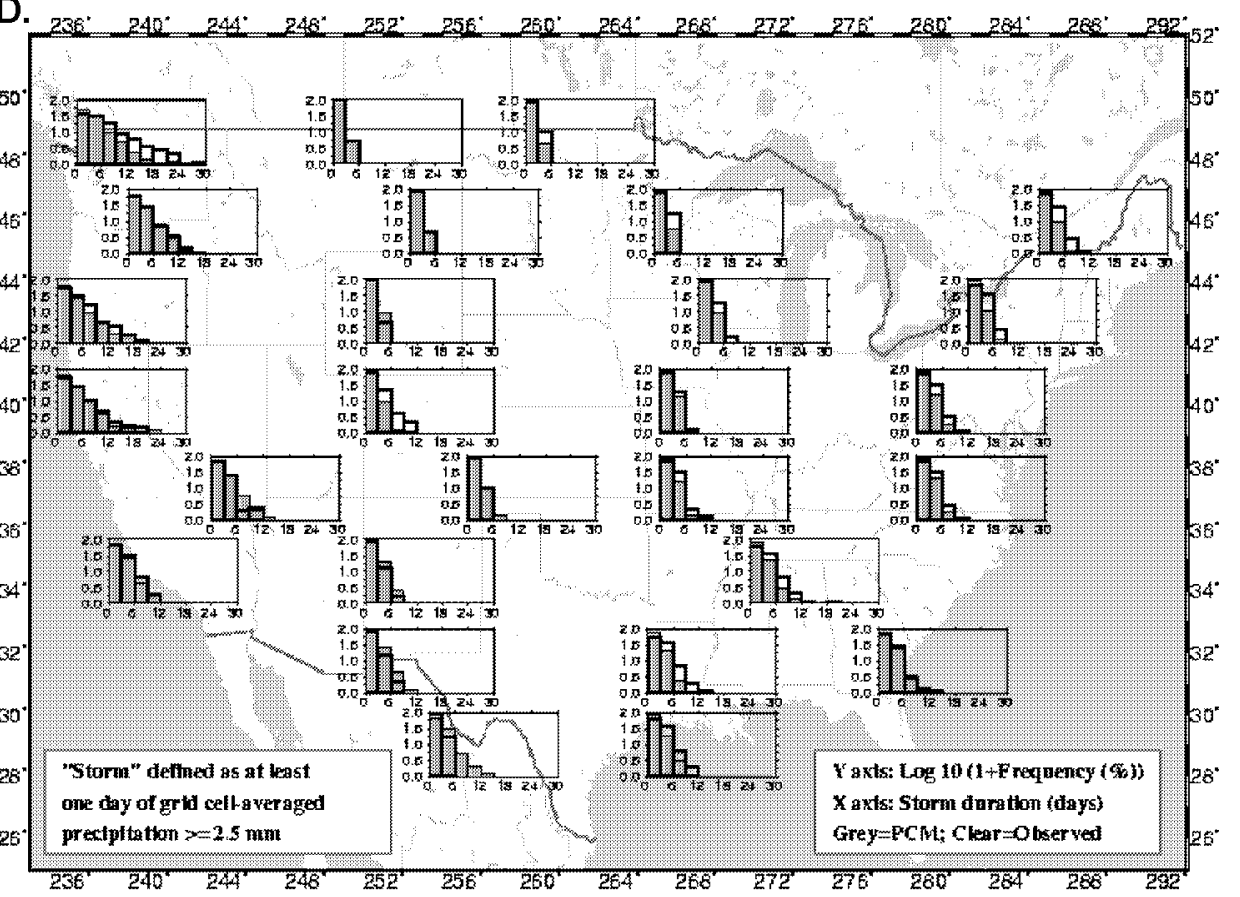

Figures $2 c, d$. Daily storm statistic distributions for PCM and observations, 1950-1999: (c) Winter (DJF) storm interarrival distribution; (d) Winter (DJF) storm duration distribution. 
Diurnal cycle comparison: Comparison of the diurnal cycle of model precipitation with observations can help in understanding how the hydrological cycle interacts with clouds and radiative fluxes. Evaluation of longer time accumulations (e.g., monthly means) can then be more meaningfully interpreted in light of the model physical parameterizations (Lin et al., 2000). Figures 3a,b compare the mean diurnal cycle of precipitation for summer (JJA) and winter (DJF) with observations. In summer, PCM generally exhibits a much stronger diurnal variation than observed. The model has a precipitation maximum in the afternoon over most of the inland part of the U.S., and in the early morning and night over coastal areas like the southeastern U.S. and Gulf Coast. The timing of the diurnal maximum matches observations reasonably well in the Northwest and Northeast, although the model amplitude is larger than in the observations. In the Northern Great Plains and north central United States, the model is badly out of phase with observations, which show a nocturnal maximum not produced by the model. PCM also poorly simulates the diurnal cycle in the Southeast, where the model shows a pronounced afternoon maximum, while the observations show that precipitation is relatively uniformly distributed throughout the day. Even in cases where the observed and simulated amplitudes are similar, there tends to be a phase shift with PCM peaking before the observations. For example, in Colorado, there is a timing shift with the model leading the observations by about 3 hours. In winter, the model and observations are quite similar, with both having only minimal variations in the incidence of precipitation throughout the day.Overall, in summer PCM shows stronger diurnal variations in the incidence of precipitation than is observed. The model incorrectly predicts an afternoon maximum in precipitation in the Northern Great Plains and north central United States, and an early morning maximum along the southeastern coast. The diurnal variability of summer precipitation mainly reflects the diurnal cycle in convective activity. Wallace (1975) suggested that land and sea breeze circulations in coastal areas result in a uniform diurnal heating cycle in regions of sloping terrain, and that diurnal changes in frictional drag of the planetary boundary layer may induce diurnal variations in low-level convergence that control the timing of convective rainfall over land and coastal areas during summer. In his theory, the combined effects of solar heating over sloping terrain and changes in frictional drag of the planetary layer lead to a nocturnal maximum in convective activity over the central United States (Wallace, 1975); this maximum is apparent in Figure 3a. In contrast, the PCM model physical parameterizations leads to an afternoon precipitation maximum over most of the inland area of the U.S., and does not capture the convective activity pattern in Northern Great Plains and north central United States.

\subsection{SURFACE AIR TEMPERATURE}

Annual and seasonal comparison: Previous studies (e.g., Bonan, 1998) have shown that PCM generally simulates well the surface climatology of moist midlat- 
A.

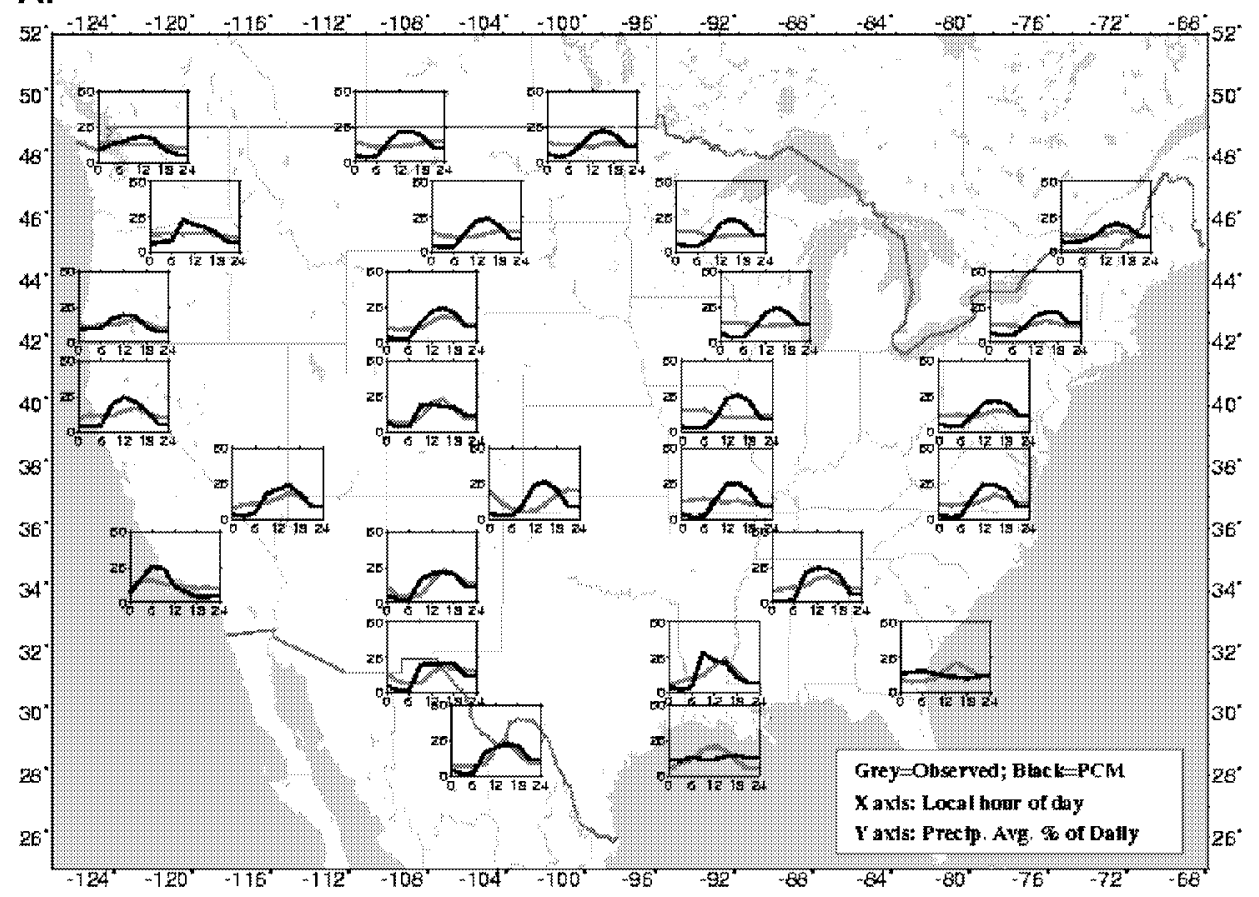

B.

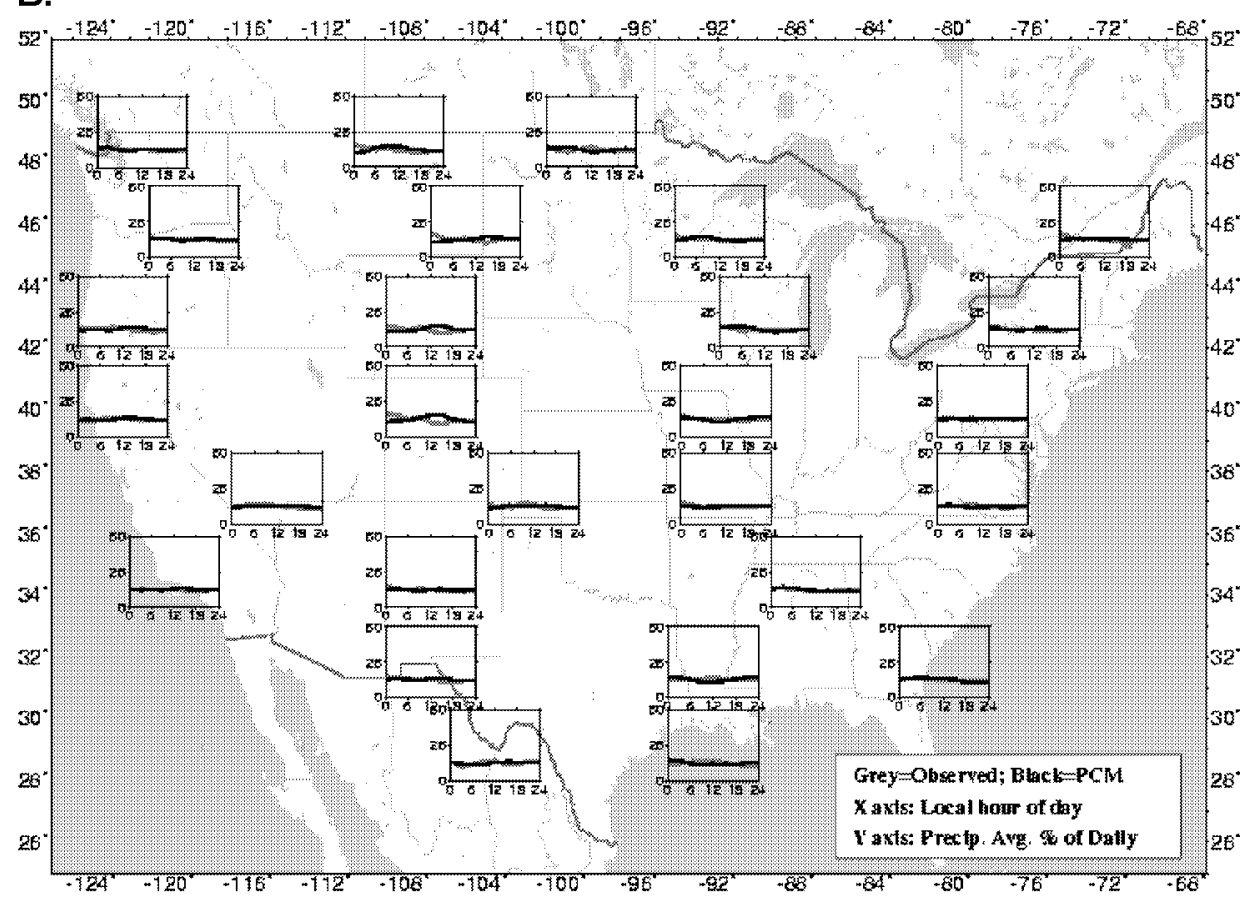

Figure 3. Mean diurnal cycle of precipitation from PCM and observations, (a) Summer and (b) Winter. 
itude regions, but underestimates surface air temperature in arid regions. Figure 4 shows the annual and seasonal spatial patterns of PCM and observed monthly mean air temperatures. PCM tends to underestimate the annual average air temperature over most of the U.S. except in some coastal areas in the East and West, and some parts of the in Southeast. As indicated by Bonan (1998), the most severe underestimates occur in the arid Southwest, and in some parts of the central U.S. where maximum differences in the annual average can be about $-6 \mathrm{~K}$. Unlike precipitation, the patterns of temperatures have some sharp changes in some cells along the Rock Mountains. For example, in the vicinity of the Rocky Mountain Front Range, PCM has a slight warm bias of about $1 \mathrm{~K}$, but immediately to the east there is negative deviation of about $-4 \mathrm{~K}$. These differences may to some extent be attributable to biases in the model's mean grid cell elevations as contrasted with those of the observations, which are corrected for the true topography.

Seasonally, the largest differences between model and observations occur in spring, and especially in the central and western parts of the U.S., where differences as large as $-8 \mathrm{~K}$ occur. This large cold bias is probably related to the underestimation of snow by PCM in this region (see Section 3.5). PCM overestimates the total precipitation in spring in these areas by about $100 \mathrm{~mm}$ (Figure 1), and due to the underestimation of snow PCM has an implied positive bias of liquid precipitation of much more than $100 \mathrm{~mm}$ in some areas. The excessive rainfall probably contributes to this cold bias of PCM due to enhanced latent heat at the land surface. In winter, the model has a substantial cold bias, especially in the western, southwestern, and northeastern U.S. where cold deviations exceeding $-8 \mathrm{~K}$ are found. In summer, the largest underestimates are to the east of the Rocky Mountains, and may be associated with the strong deep convection that occurs there. The excessive model precipitation over the mountainous west tends to result in excessively wet soils in summer, which cause high latent heat flux, low sensible heat flux, and surface cooling (Bonan, 1998). On the other hand, annual average (and especially summer and fall) temperatures in the Southeast and West are slightly overestimated by the model. Autumn is the best-simulated season for PCM, with temperature differences varying from $-2 \mathrm{~K}$ to $2 \mathrm{~K}$ over most of the U.S.

Diurnal cycle comparison: Clouds, combined with secondary damping effects from soil moisture and precipitation, determine the geographic patterns of the diurnal range of surface air temperature. Clouds can reduce $T_{\max }$ by reflecting sunlight and reducing downward solar radiation at the surface, and increase $T_{\min }$ by enhancing downward long-wave radiation. Increasing soil moisture increases surface latent heat releases and suppresses temperature rise during the day; therefore precipitation affects the temperature range mainly through its effect on soil moisture (Dai et al., 1999b). On the other hand, sensible heat offsets a large part of the latent heat anomalies, making soil moisture less effective in damping diurnal variability of air temperature.

Figures 5a,b compare the PCM mean diurnal cycle of surface air temperature with that of observations for spring (MAM) and summer (JJA). PCM tends to 


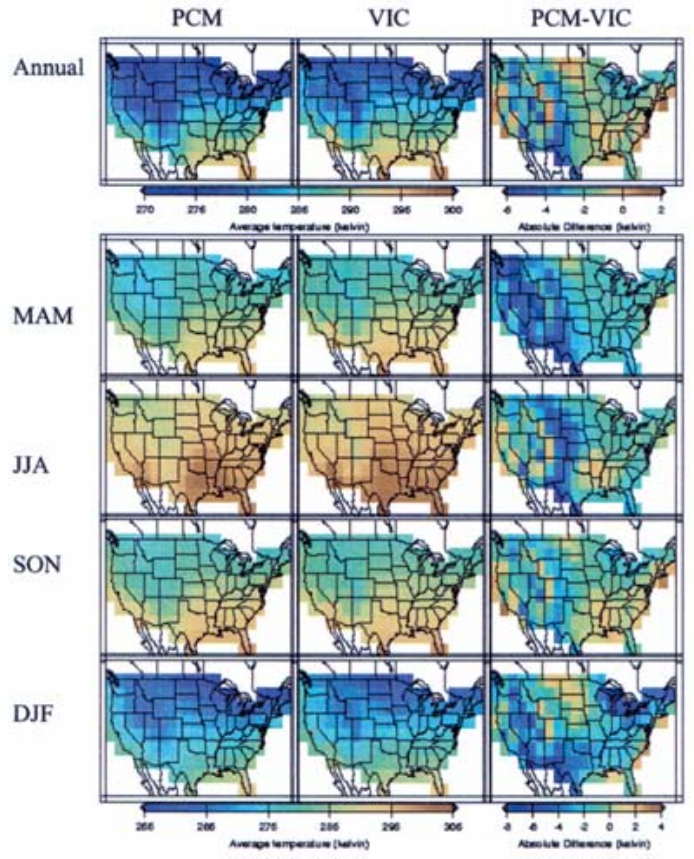

Figure 4. Mean annual and seasonal surface air temperature for PCM and observations.
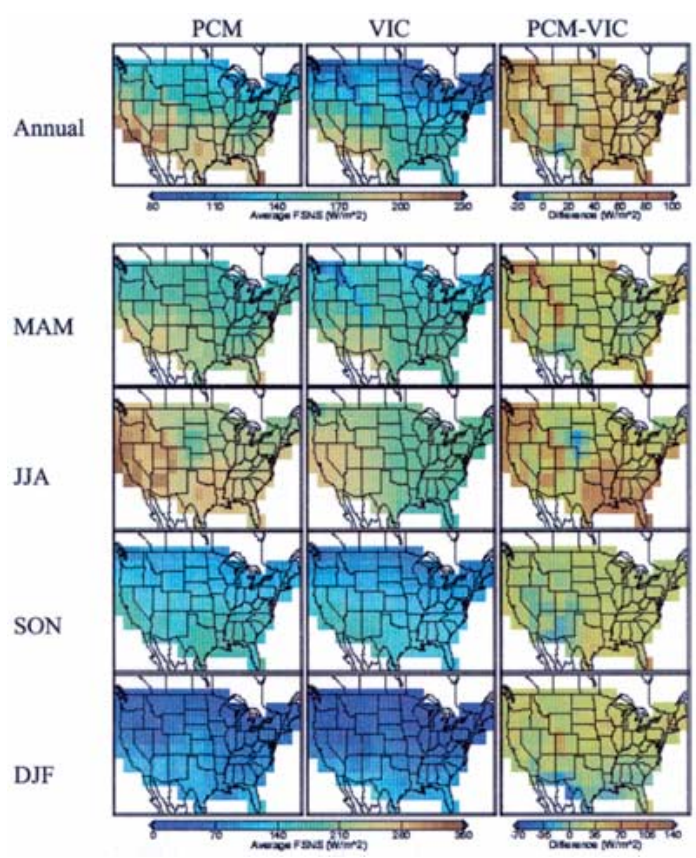

Figure 6. Mean annual and seasonal net surface downward short-wave radiation flux PCM, and derived from daily temperature range using algorithm of Thornton and Running (1999). 
underestimate the amplitude of the observed diurnal cycle in air temperature, especially in the spring, and particularly in the central and western parts of the country. In the central U.S., the suppressed diurnal cycle is consistent with overestimated precipitation. An alternative explanation that would associate the bias with cloud cover mis-estimation does not appear viable because PCM overestimates surface solar radiation (see Section 3.3). Figure 5b shows that the underestimate by PCM of the observed amplitude of the diurnal air temperature variation is much reduced in summer as compared with spring.

In addition to biases in the magnitude of the diurnal variations in air temperature, the model simulates the time of maximum daily air temperature $1 \sim 2$ hours too early in the central U.S.. In winter PCM has a similar bias (slightly reduced diurnal temperature range) over most of the region.

\subsection{SHORT-WAVE RADIATION}

Annual and seasonal comparison: Solar radiation drives atmospheric circulation. Because CCM3 is the atmospheric component of PCM, the accuracy of the surface fluxes is important for the land, ocean, and sea-ice components of PCM. Our comparisons are on the basis of net shortwave radiation, because this is the only variable that is consistently defined in the PCM and Maurer et al. (2002) archives. It should be noted that differences could be attributable to differences in albedo between LSM and VIC, and/or differences in downward solar radiation. We also caution that while the solar radiation values in Maurer et al (computed using the algorithm of Thornton and Running, 1999) have been evaluated with direct observations at a few points, as have the VIC albedos, these 'observations' are themselves subject to errors. Figure 6 shows the annual and seasonal spatial patterns of net downward solar radiation for PCM, and VIC-derived quantities. On an annual basis, PCM net solar radiation tends to exceed the gridded derived values over most of the country except in parts of the Southwest, where the PCM values are slightly lower by about $10 \mathrm{~W} / \mathrm{m}^{2}$. Zhang's (1998) comparison with Global Energy Balance Archive station data also showed that CCM3 surface shortwave fluxes are biased high, which Kiehl (1998) attributed to the CCM clouds' insufficient absorption of shortwave radiation. PCM matches the gridded derived values quite well in the central part of the U.S. to the east of the Rocky Mountains, and in parts of the Southwest and West where there are less than $10 \mathrm{~W} / \mathrm{m}^{2}$ positive deviations. This result agrees with Kiehl (1998) who found that although the model did not simulate upperlevel clouds associated with summer convective activity, total cloud cover (which strongly affects downward shortwave radiation) was reasonably well predicted in the central U.S. Positive deviations $\left(>60 \mathrm{~W} / \mathrm{m}^{2}\right)$ were found to the west of the Rockies and some cells in Idaho. The spatial distribution of these biases is similar to the spatial patterns of temperature differences (Figure 4), with a sharp gradient in the vicinity of the Continental Divide. This apparent correspondence is reasonable considering the close relationship between surface air temperature and net surface 
A.

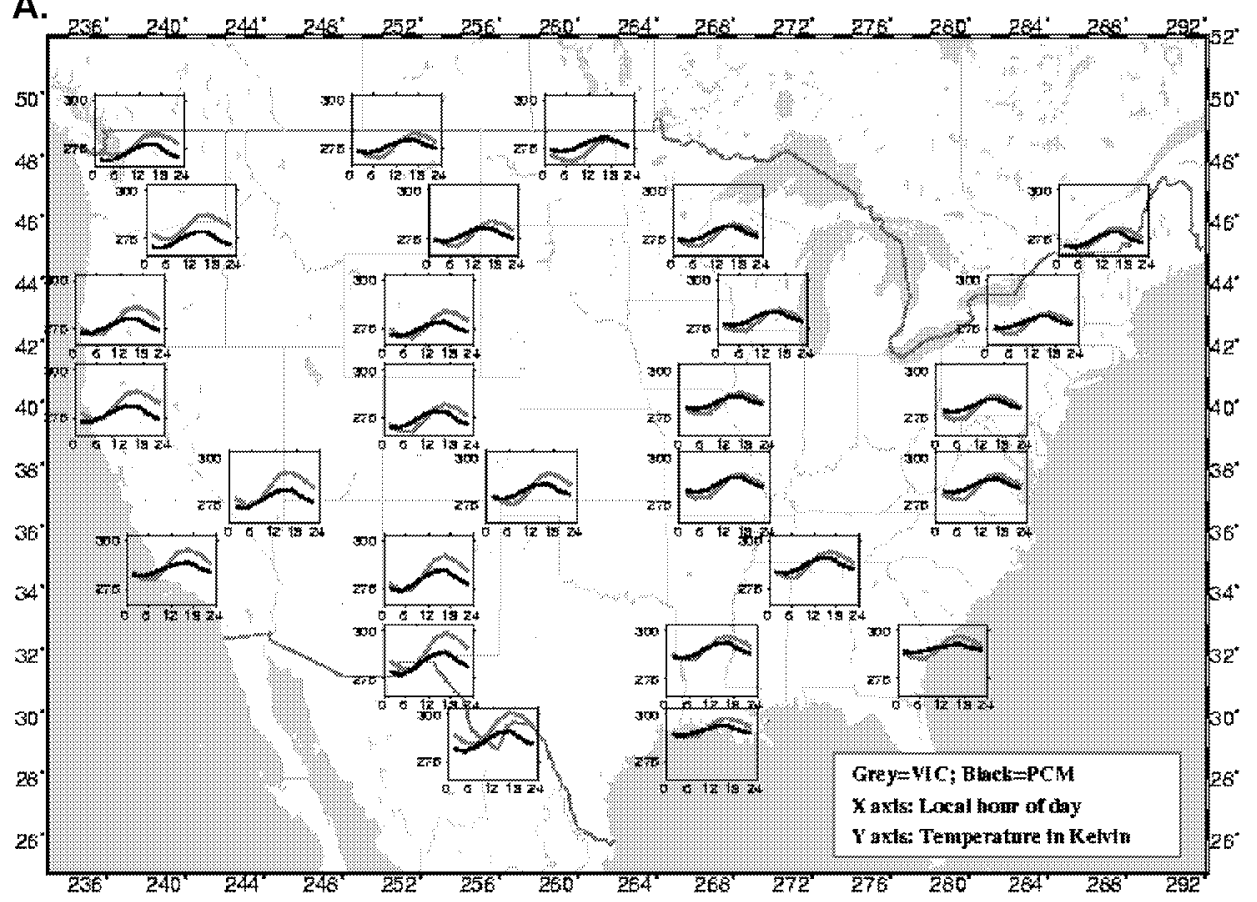

B.

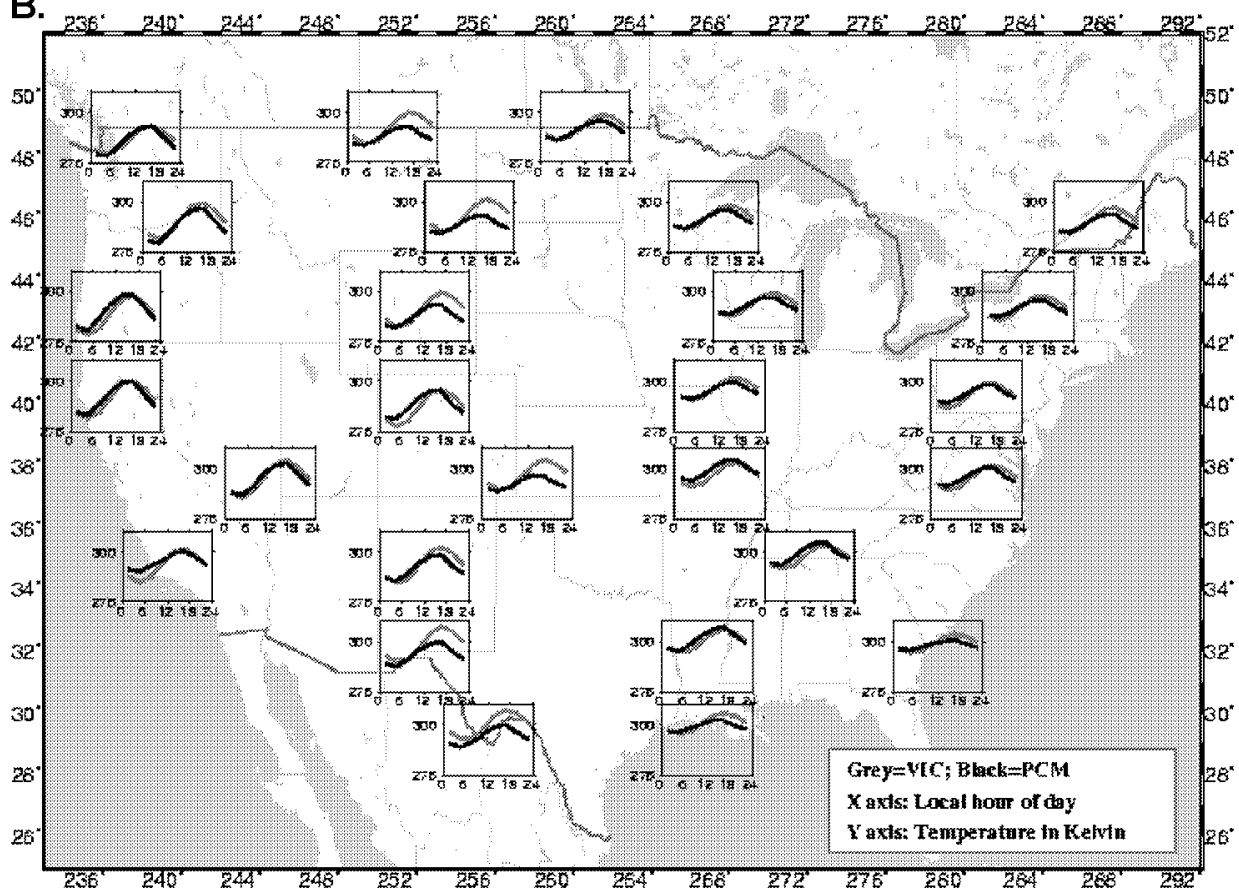

Figures 5a,b. Mean diurnal cycle of surface air temperature for PCM and observations, (a) Spring, (b) Summer. 

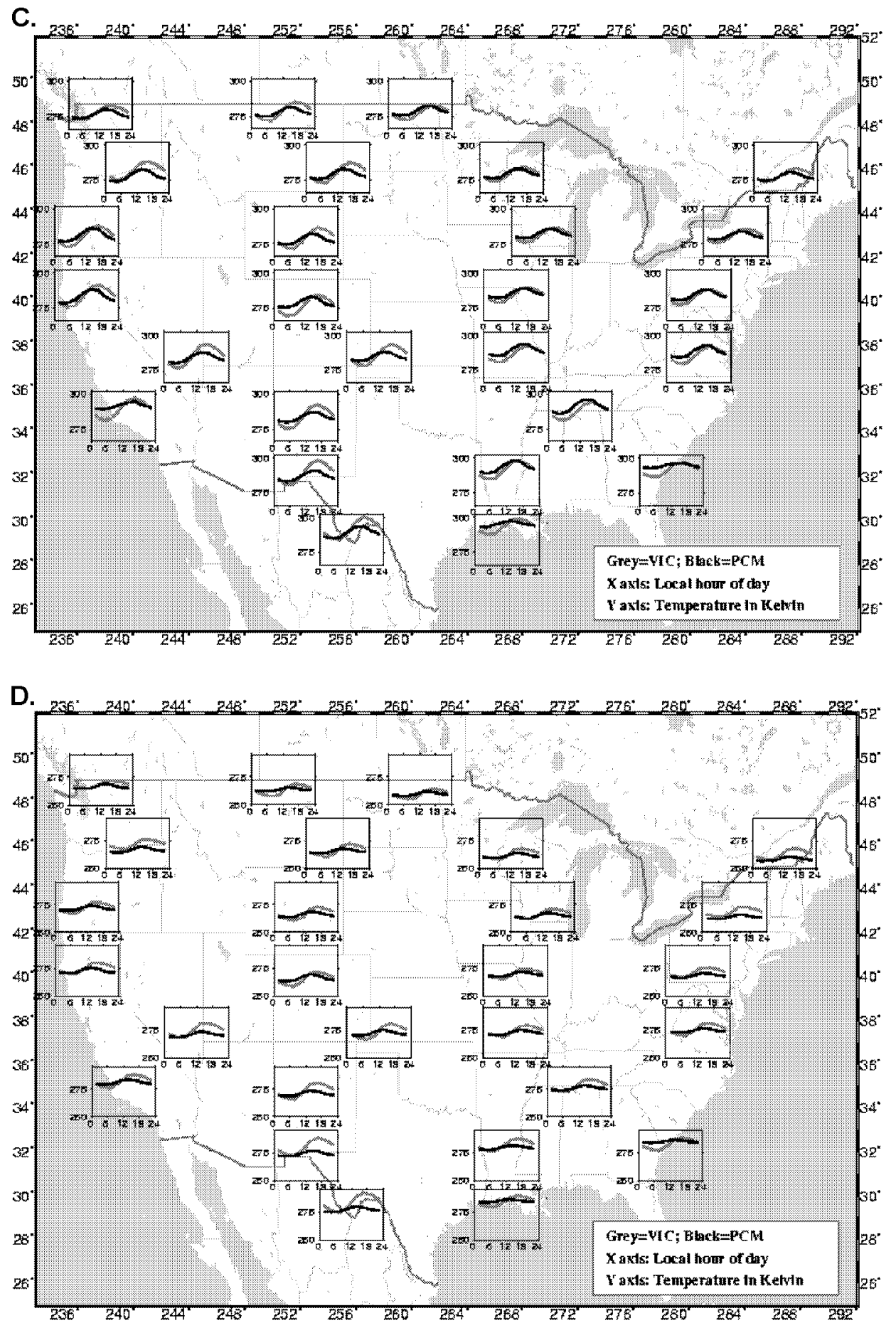

Figures $5 c, d$. Mean diurnal cycle of surface air temperature for PCM and observations, (c) Autumn and (d) Winter. 
short wave radiation. The deviation in other areas ranges mostly from $20-60 \mathrm{~W} / \mathrm{m}^{2}$. On a seasonal basis, PCM agrees with VIC-derived quantities best in spring over most of the country. The highest positive deviations $\left(>100 \mathrm{~W} / \mathrm{m}^{2}\right)$ in spring and in summer occur in the mountainous west, and are the main contributions to the annual positive deviations there. Over larger areas, the summer PCM simulations are strongly biased upwards in the Southeast $\left(>70 \mathrm{~W} / \mathrm{m}^{2}\right)$ and West (by about the same amount). Autumn PCM values are downward biased in parts of the Southwest $\left(>20 \mathrm{~W} / \mathrm{m}^{2}\right)$, and are upward biased in the Southeast (about $\left.40 \mathrm{~W} / \mathrm{m}^{2}\right)$. In winter, PCM is downward biased in the Southeast $\left(>20 \mathrm{~W} / \mathrm{m}^{2}\right)$ and upward biased in the Northeast and Northwest (about $40 \mathrm{~W} / \mathrm{m}^{2}$ ). The spring and winter upward bias in the mountainous west is also probably related to downward bias in the PCM snow cover (see Section 3.5). The lower surface albedo associated with PCM snow underestimation is expected to contribute to the upward bias of net downward solar radiation.

Diurnal cycle comparison: Figure 7 compares the diurnal cycle of net solar radiation (SW) for PCM and the gridded derived values for autumn and summer. PCM agrees with the VIC values reasonably well in spring, summer and winter (not shown). The surface net SW fluxes tend to follow the daytime solar insolation and peak around local noon. In autumn (Figure 7a), the PCM values tend to have higher noontime SW than the gridded derived values. The difference trend is similar over most of the U.S. at about 5-10 percent. For the summer comparisons (Figure 7b), the differences in maximum daily SW are generally larger, and these differences may account for much of the annual differences shown in Figure 6. It should be noted that Maurer et al. (2002), and subsequent analyses show that while the derived values tend to reproduce direct observations at SURFRAD sites reasonably well in the daily mean, the derived values are biased down somewhat in the daily maximum. Hence, apparent biases in PCM daily maxima may be to some extent a reflection of biases in the derived values. Figure $7 \mathrm{~b}$ shows that the summer daily SW maximum in PCM is higher than VIC in almost all cells, and in the West and Southeast the positive deviation can be more than $100 \mathrm{~W} / \mathrm{m}^{2}$. Based on Figures 6 and 7, it seems likely that the PCM SW is biased upward somewhat, but that the amount is probably less than indicated in the figures, as the VIC-derived values likely have a slight downward bias.

\subsection{SOIL MOISTURE}

Comparison of soil moisture between models is fraught with difficulties, since the dynamic equilibrium of a land scheme's soil moisture depends strongly on its process parameterizations. However, changes in total water storage should be more comparable between models than soil water storage because the storage change is the relevant term in the land surface water balance (Schaake et al., 2003). Figure 8 compares the annual and seasonal soil moisture range from PCM and VIC 50year simulations. In general, the PCM ranges are much less than those of VIC, 
A.

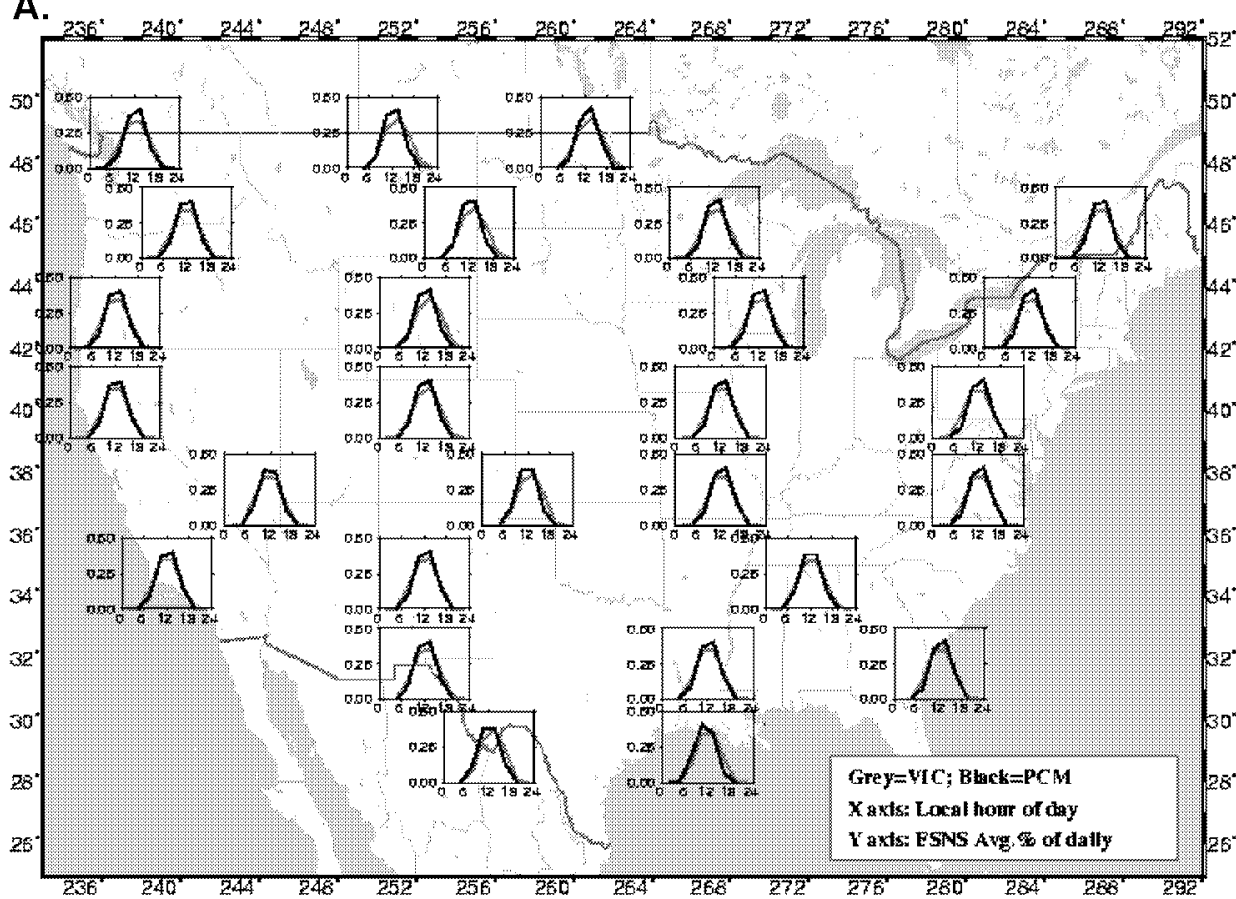

B.

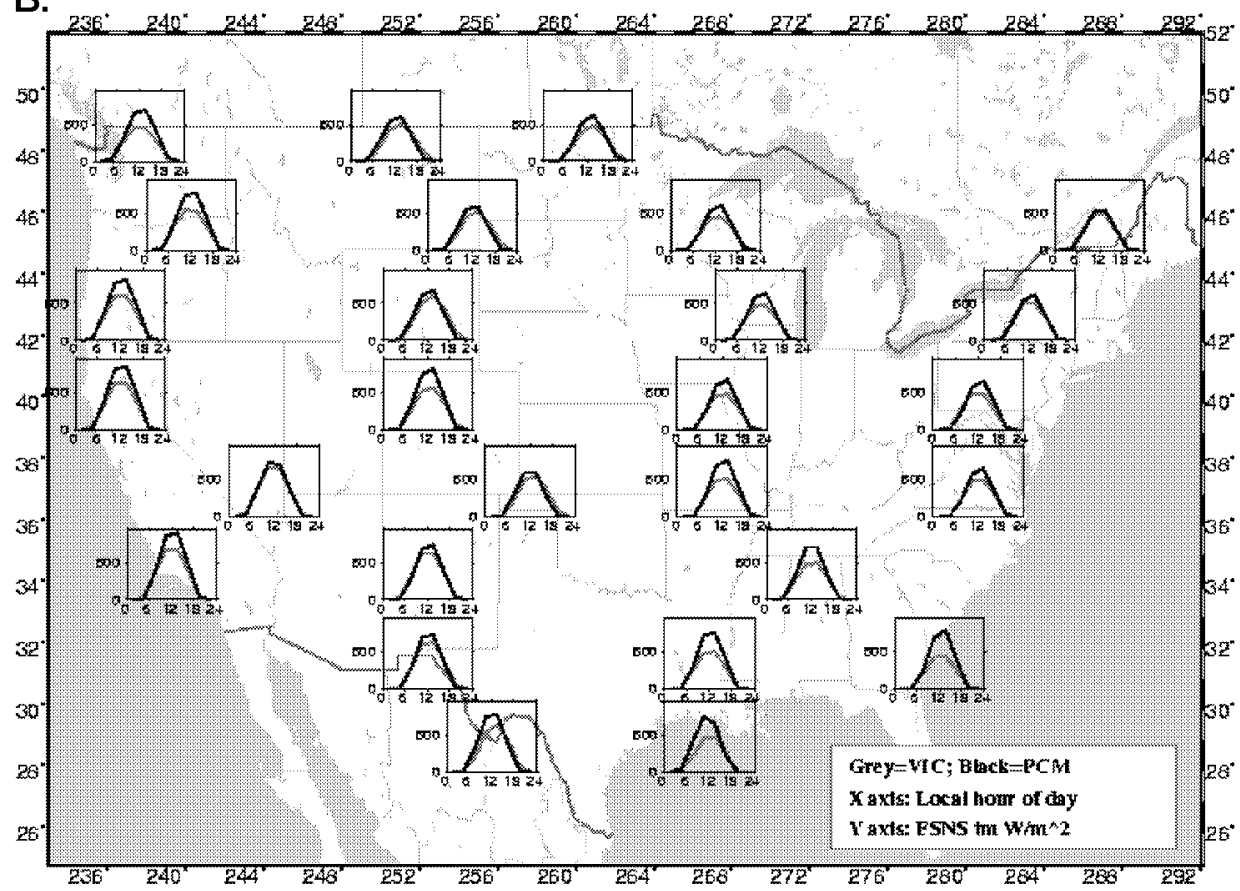

Figure 7. Mean diurnal cycle of net surface downward short-wave radiation from PCM, and derived from daily temperature range using algorithm of Thornton and Running (1999), (a) Autumn, (b) Summer. 
which implies that the PCM soil moisture is less dynamic. In one case where long records of observed soil moisture were available (over Illinois), Maurer et al. (2002) showed that the VIC dynamic range matched that of a long-term set of observations quite well, therefore it is worth focusing on this part of the U.S. Here, the PCM ranges tend to be much less than those estimated by VIC (and by inference, direct observations). On the other hand, in parts of the West the PCM range is slightly higher than VIC's. Over most of the country, and for most seasons, however, the PCM soil column has less variability than VIC's, and in many locations (especially the Midwest), much less so.

\subsection{SNOW WATER EQUIVALENT}

As noted above, winter snow accumulation is a key process in much of the western U.S., a region of special interest to ACPI. Figure 9 compares the annual and seasonal snow water equivalent depth (SWE) from PCM and VIC 50-year simulations. Generally, PCM values are lower than VIC SWE, especially in the mountainous parts of the west (Rocky Mountains and Cascade/Sierra Nevada) and the northeastern corner of the U.S. (northern part of the Appalachian Mountains). Pan et al. (2002) compared SWE predictions of four land surface models including VIC with observations at a number of locations throughout the western U.S. They found that all models had systematic low biases relative to observations, although the VIC biases were generally smallest in absolute value. The differences were especially large in the Cascade and Sierra Nevada mountains, which are the areas of highest observed snow accumulation. This implies that the true PCM biases are probably larger than those implied by comparisons with the VIC-derived values. The low SWE bias in PCM is likely related to its use of average elevation in each grid cell rather than representing high elevation areas as a separate class or classes, which results in less precipitation falling as snow and more as rainfall on average over grid cells in mountainous areas.

\section{ENSO}

The El Niño-Southern Oscillation (ENSO) cycle is known to affect wintertime precipitation over North America (e.g., Ropelewski and Halpert, 1986; Gershunov and Barnett, 1998, among others). The strong expression of the ENSO signal on western U.S. wintertime precipitation, and associated snow accumulation, is of particular interest for the ACPI pilot project. Therefore, it is important to evaluate PCM's simulation of ENSO and its effects on precipitation in the western U.S.

Figure 10 shows the leading EOF of detrended wintertime (DJF) sea surface temperature (SST) anomalies over the Pacific basin. Observed SSTs are taken from da Silva (1995) for the period 1946-1992. Comparing the model results to observations, it can be seen that the model captures the general pattern. The 


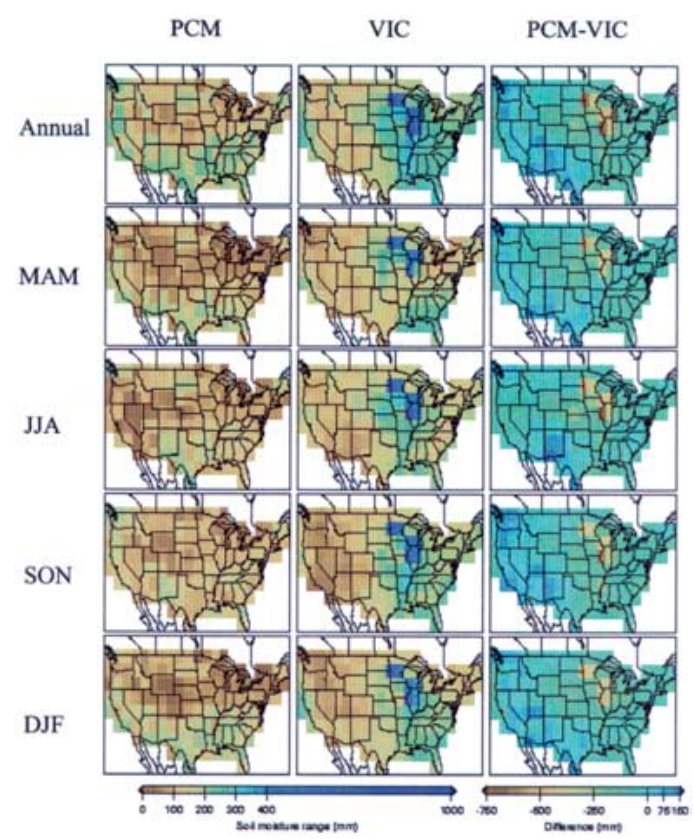

Figure 8. Annual and seasonal predicted soil moisture range (1950-1999) for PCM and off-line simulations with Variable Infiltration Capacity (VIC) model from Maurer et al. (2002).
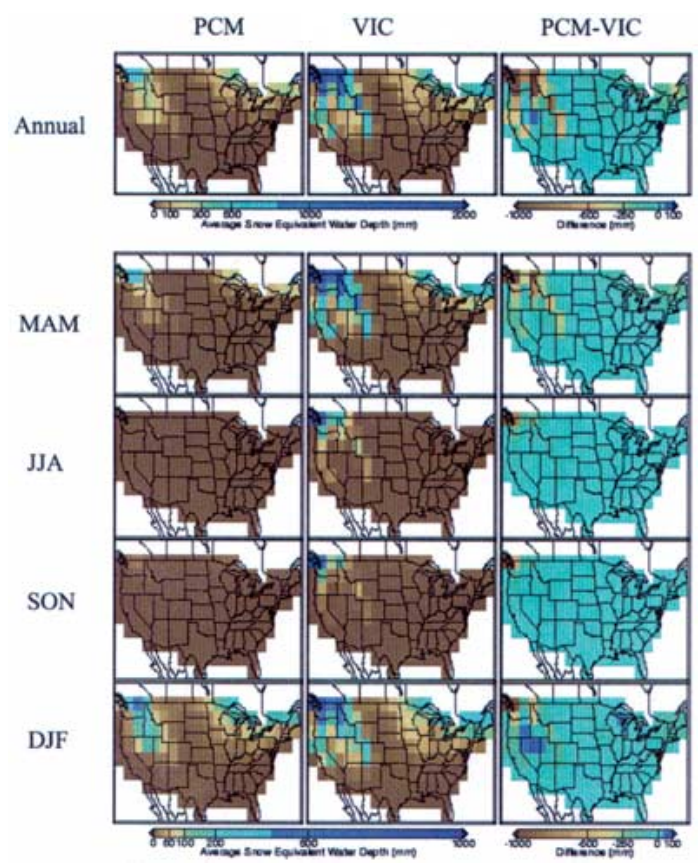

Figure 9. Annual and seasonal predicted mean snow water equivalent depth (1950-1999) for PCM and off-line simulations with Variable Infiltration Capacity (VIC) model from Maurer et al. (2002). 
A.

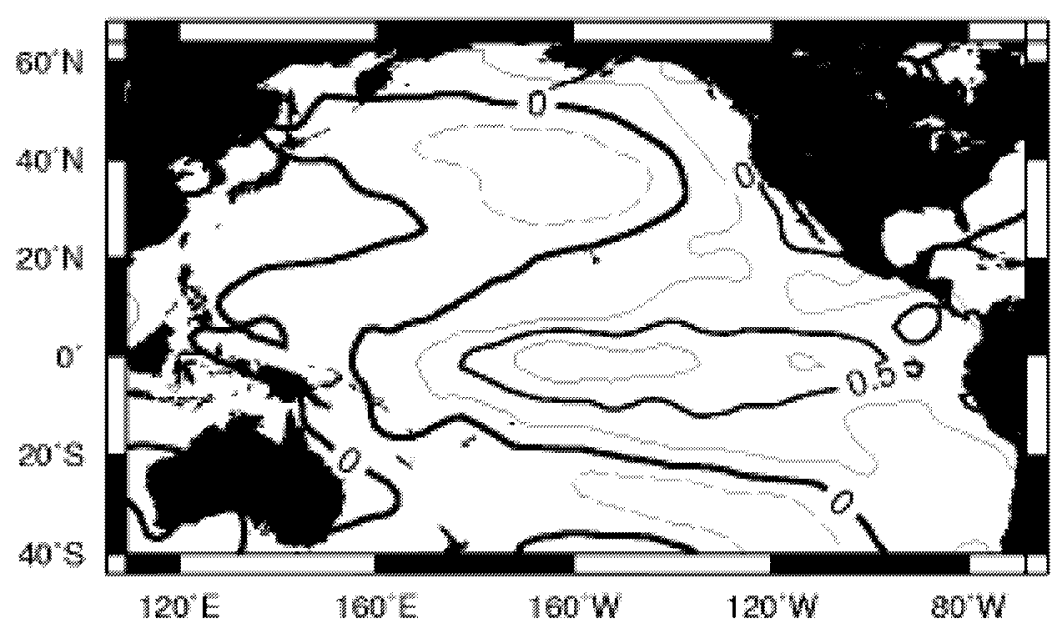

B.

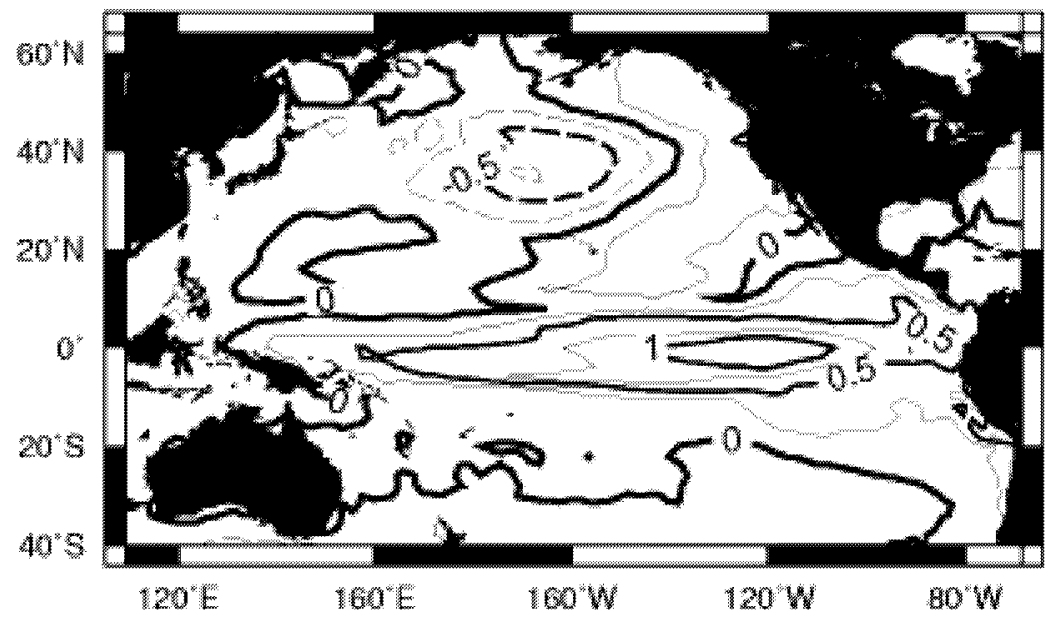

Figure 10. Leading EOF of SST monthly anomalies from detrended observations over the period 1945-1993 (a) and PCM (b). Values are in degrees K for one standard deviation of the associated principal component. Contour interval is $0.25 \mathrm{~K}$.

greatest variability is confined to the equatorial wave guide, with smaller, samesign expression along the west coast of North America. There is a center of action with opposite sign in the central North Pacific, which is believed to be driven by a teleconnected wind response (Deser and Blackmon, 1995). The positive loading along the equator extends about 30 degrees of longitude too far to the west. For unknown reasons, this particular error is symptomatic to many current-generation coupled OAGCMS (Mechoso et al., 1995). The center of action along the equator is modestly too strong ( $1.0 \mathrm{~K}$ for the model versus $0.8 \mathrm{~K}$ for the observations), while 
in the central North Pacific is considerably too strong ( $-0.6 \mathrm{~K}$ for the model, $0.2 \mathrm{~K}$ for the observations). This suggests PCM might have an exaggerated extratropical response to equatorial variability. In the model, the ENSO mode accounts for $23 \%$ of the monthly SST anomaly variability; in the observations, it is $24.5 \%$. These values are not significantly different given sampling variability.

The mechanism through which the equatorial signal is carried to North America is by atmospheric teleconnections. One way of visualizing this is by correlating global yearly sea level pressure anomaliess with those at Darwin, Australia, as was done by Trenberth and Shea (1987). A similar correlation map using the da Silva (1995) data set is shown in Figure 11 (note that the sea level pressure data set is based on methods that produce values over ocean only, hence there are no values over land). The main pattern is a dipole of response along the equatorial Pacific, with significant expression reaching in to the eastern North Pacific. The model correlation map (Figure 11, lower panel) captures the large scale features although the magnitude of the correlations in the eastern tropical Pacific is weaker than observed and the maximum lies along the equator instead of displaced to the south. The expression over the North Pacific is close to the observed pattern in magnitude and location, however.

These global variations in sea level pressure are associated with changes in paths of storm systems. ENSO therefore has known effects on winter precipitation over North America (e.g., Gershunov and Barnett, 1998). This can be examined by compositing DJF precipitation anomalies based on the state of an ENSO indicator, taken here as the nino3.4 index (SST anomalies averaged over the box $5^{\circ} \mathrm{N}$ to $5^{\circ} \mathrm{S}$, $140^{\circ} \mathrm{W}$ to the international dateline). The precipitation composites are illustrated for observations and the model in Figure 12. The composites shown were formed by differencing the precipitation anomalies for the $10 \%$ most positive nino3.4 index winters (El Niños) and the $10 \%$ most negative (La Niñas). The observations show wetter conditions throughout the southern U.S., particularly in central California and along the Gulf of Mexico. Drier conditions prevail in the Pacific Northwest and central Ohio valley. The model, with a resolution of about 2.8 degrees, cannot capture the details of the response, but the increased precipitation in central California and the southeastern U.S. can be seen. The model also misses the moderate response over the southwestern U.S. seen in the observations, potentially leading to an underestimation of ENSO forcing on water supplies in the region. For the purposes of western U.S. water supplies, the most noticeable deficiency is that, in the model, the drier conditions the Pacific northwest experienced in El Niño as compared to La Niña years are too weak $(-0.5 \mathrm{~mm} /$ day compared to $-1.0 \mathrm{~mm} /$ day in the observations) and shifted to the north. It has been speculated that an important effect of anthropogenic forcing might be to alter ENSO's frequency (Cane et al., 1997; Timmerman et al., 1999), but these studies do not agree as to what the sign of the response should be. In any event, if such an alteration of ENSO is important for forcing regional shifts in climate, the pilot-ACPI runs will have a response over the Pacific Northwest that is too weak and shifted northwards. 

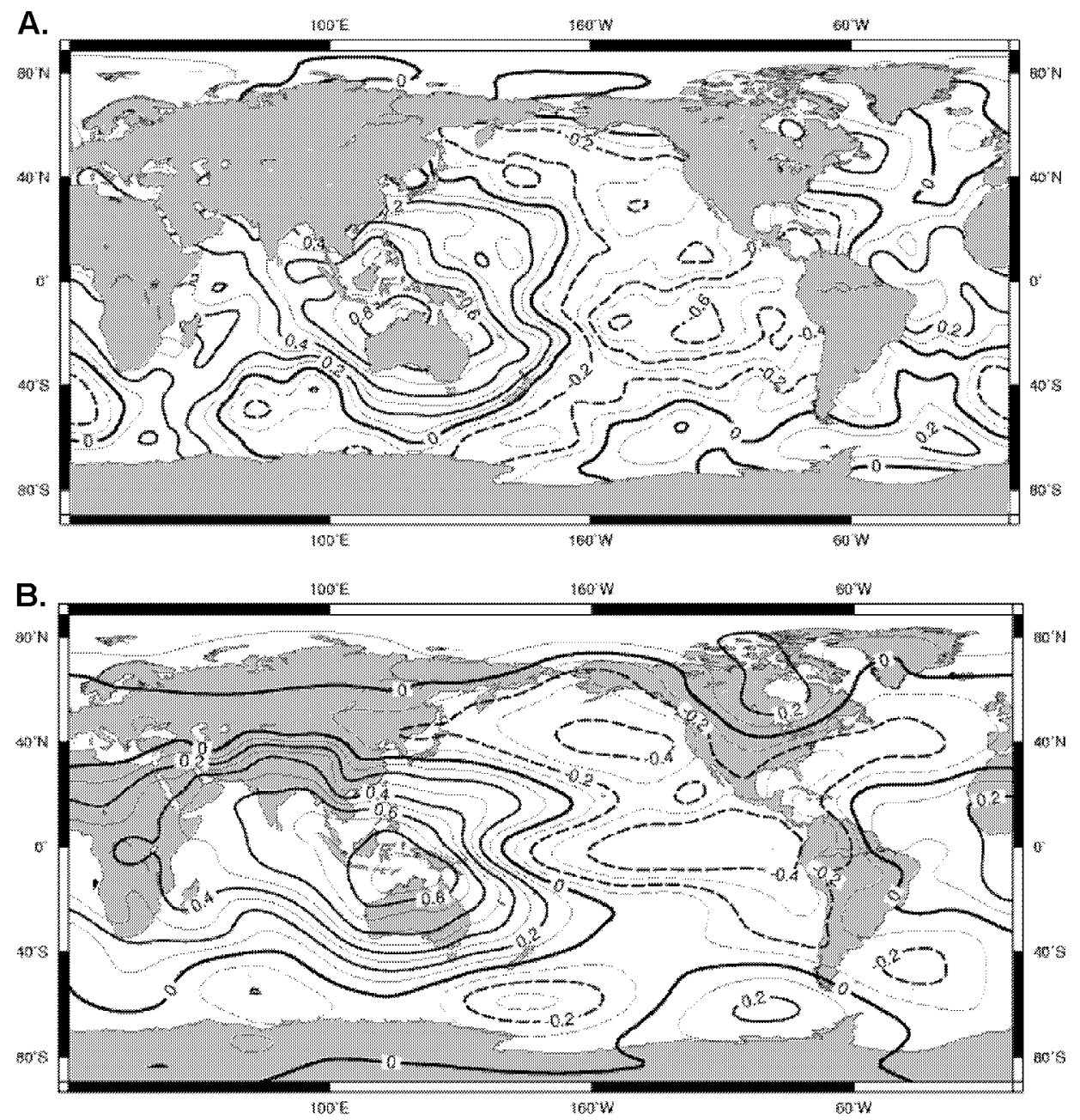

Figure 11. Correlation map of annual average sea level pressure (SLP) anomaly over the globe with Darwin, Australia SLP. (a) Observed over the period 1945-1993 (note that there are no values over land). (b) For PCM. Contour interval is 0.1.

\section{The North Pacific Oscillation}

The North Pacific Oscillation (a variation of which is termed the Pacific Decadal Oscillation by Mantua et al. (1997)) is known to be associated with wintertime temperature anomalies over North America (Latif and Barnett, 1994; Latif and Barnett, 1996). The spectrum of the NPO is red to first order (Pierce, 2001), so these fluctuations tend to have noticeable effects over North America with decadal timescales.

Following Mantua et al. (1997), the NPO is often shown as the leading EOF of SST anomalies north of $20^{\circ} \mathrm{N}$. These are shown in Figure 13 for the observations (left panel, from the da Silva data set covering 1945-1993) and from PCM (right 


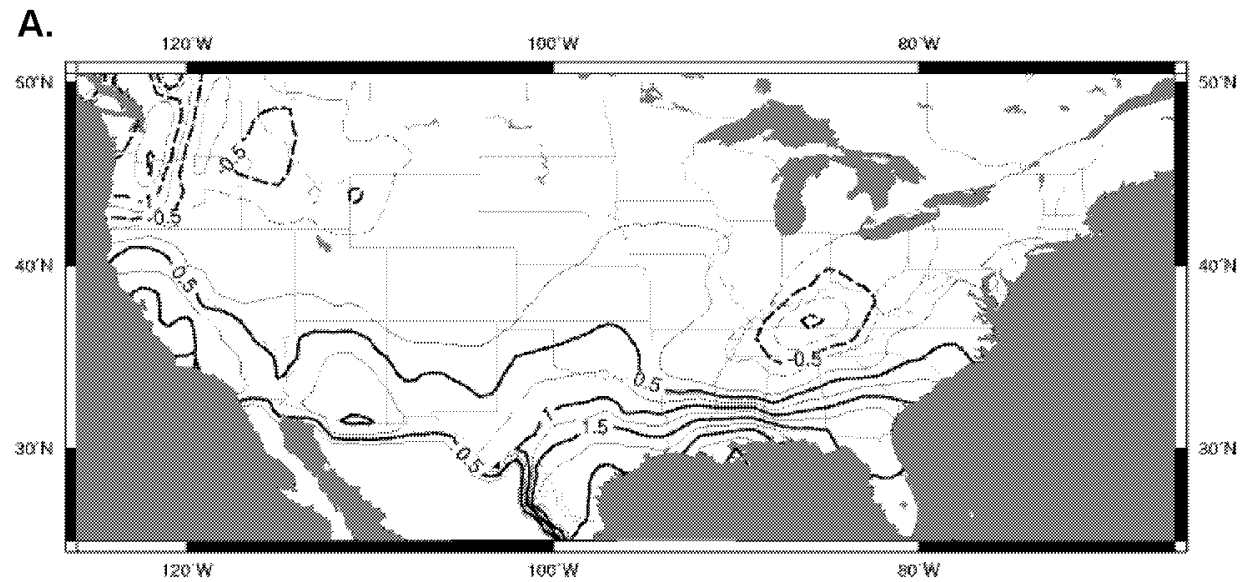

B.

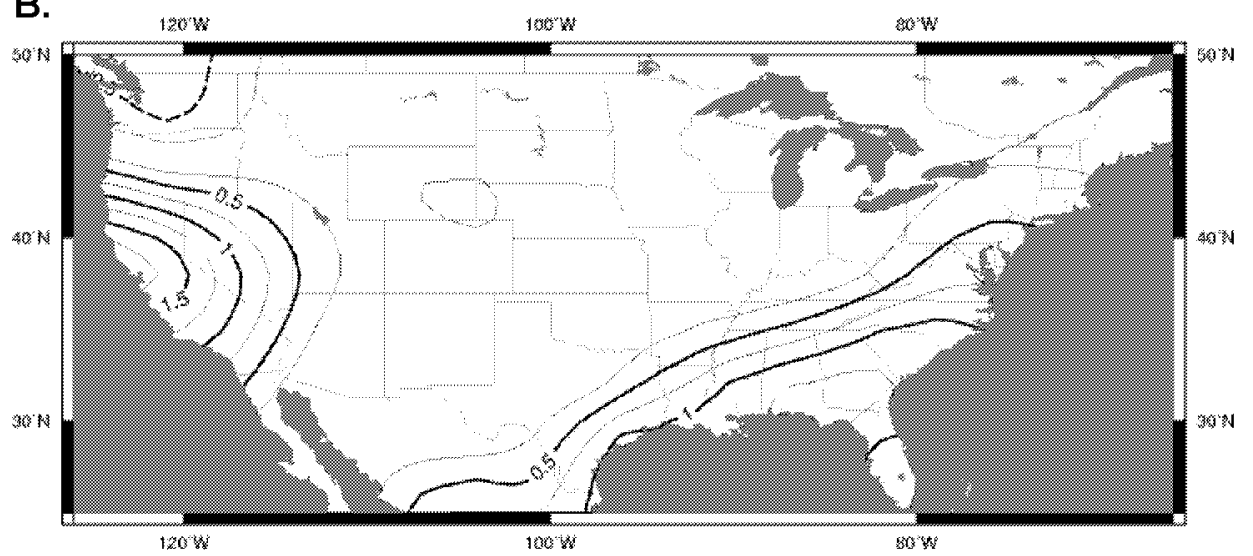

Figure 12. Composite precipitation anomaly (mm/day) associated with ENSO over the winter season. (a) Observed over the period 1945-1993. (b) For PCM. Contour interval is 0.25.

panel). The characteristic horseshoe-shaped pattern seen in the observations is reproduced by the model, although the response is too strong in magnitude (about $1.0 \mathrm{~K}$ in the central North Pacific for the model, versus $0.6 \mathrm{~K}$ in the observations). The leading EOF accounts for $26 \%$ of the variance in the observations and $35 \%$ in the model. Analysis of the standard deviation of annually averaged SST anomalies in the North Pacific (not shown) suggests that part of the model's stronger NPO response is due to an overall higher level of SST variability in the region (including at decadal timescales), and part is due to the model's greater concentration of SST variability in the leading mode.

The DJF 2-m air temperature anomalies composited on the principal component (PC) of the leading North Pacific EOF (top 10\% minus bottom 10\%) are shown in Figure 14. The observations show that the northwest part of the U.S. tends to be warm during positive phases of the NPO, while the southeastern U.S. tends to be cold. The model captures this spatial pattern reasonably well, although the 
A.

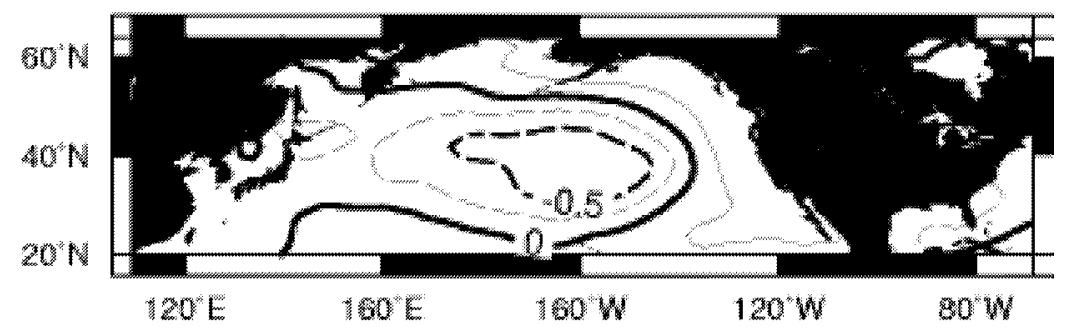

B.

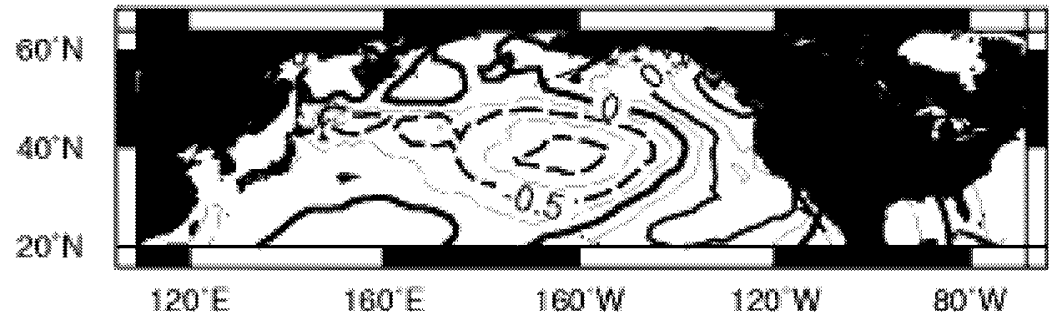

Figure 13. Leading EOF of annual SST anomalies in the North Pacific. (a) From observations over the period 1945-1993. (b) From PCM. Values are in degrees K for one standard deviation of the associated principal component. Contour interval is $0.25 \mathrm{~K}$.

maximum positive response is farther to the west than it should be (over western Oregon rather than northern Montana). The magnitude of the response is about twice as large as observed over the Pacific Northwest ( $5 \mathrm{~K}$ versus $2.5 \mathrm{~K}$ ). This is consistent with the amplitude of the forcing being about twice that observed (Figure 12).

Overall, the exaggerated strength of the NPO response over the Pacific Northwest means that the pilot-ACPI project results may be more influenced by the NPO than they should be. Reasonable steps to minimize this in subsequent phases of ACPI would include an analysis of the results in terms of the phase of the NPO seen in the individual ensemble members, and increasing the ensemble size in order to average over more phases. On the other hand, downscaled analyses of PCM output like those reported for the Columbia River basin (Payne et al., 2004, this issue), California (VanRheenen et al., 2004, this issue) and the Colorado River basin (Christensen et al., 2004, this issue) utilize multiple ensembles, which should have the effect of filtering out decadal scale variability from the climate change signal to some extent.

\section{Conclusions}

While PCM captures much of the spatial variability in precipitation over the U.S., it severely overestimates precipitation in the central U.S. and in the mountainous areas of the west, and underestimates it in the Pacific Northwest and Southeast. 

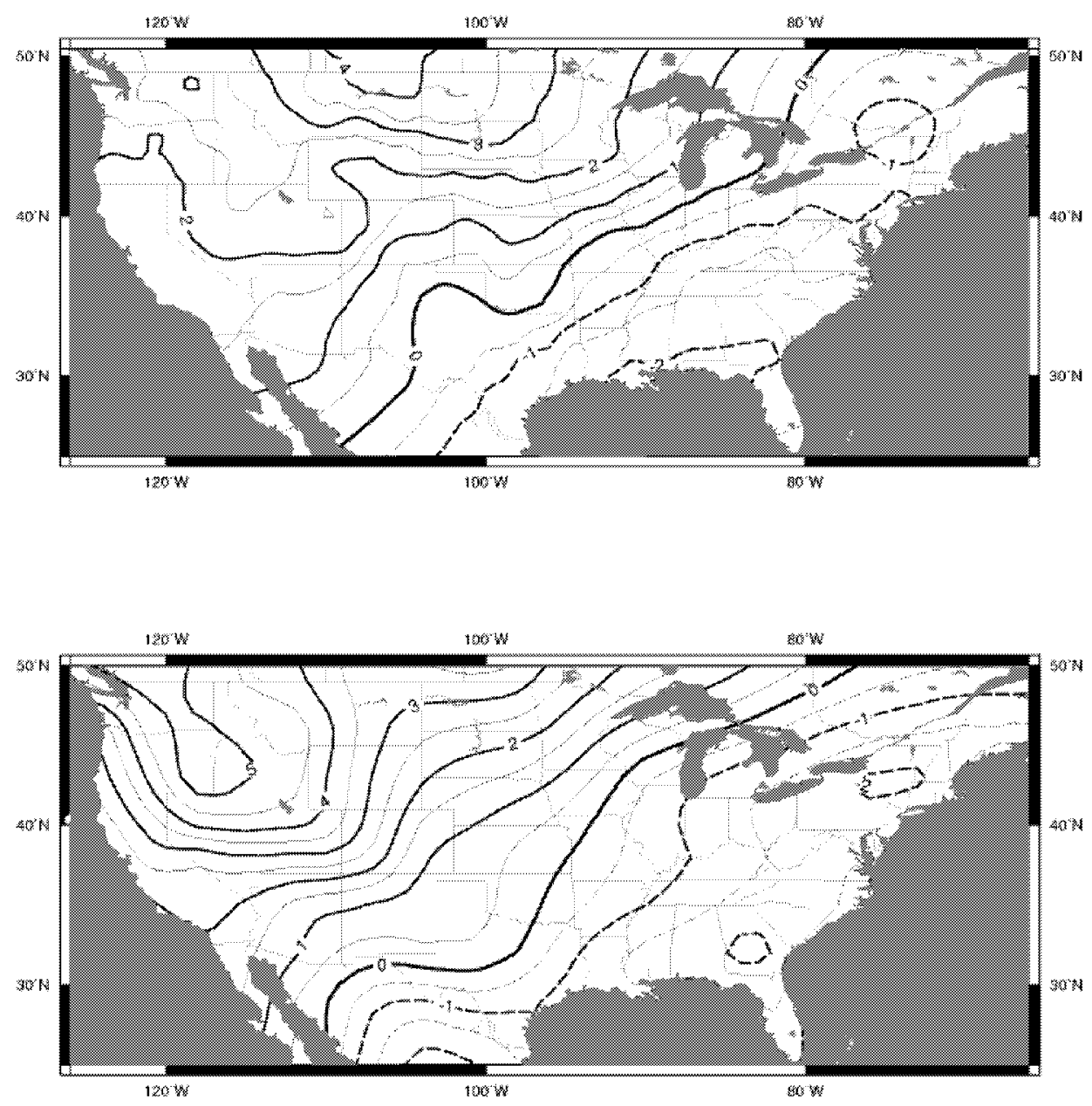

Figure 14. Composite temperature anomaly (degrees K) associated with the NPO during the winter season. (a) Observed over the period 1900-1994. (b) For PCM. Contour interval is $0.5 \mathrm{~K}$.

Furthermore, over much of the west, winter snowfall is underestimated by PCM, which implies that the amount of liquid relative to solid precipitation is greatly overestimated in the model. Autumn and spring are better simulated than winter and summer. As would be expected, biases in the dominant precipitation seasons account for much of the total: the winter dry bias in the Pacific Northwest accounts for half of the annual deviation, whereas a summer wet bias in the central U.S. accounts for much of the total positive deviation there. Summer biases in general are associated with the strong convective process and orographic locking effects of high mountain areas in PCM. The likely solution for such biases is the improvement of model physics, such as the cumulus parameterization. In the Pacific Northwest, PCM tends to give less frequent summer storms and winter storms of 
shorter duration than are observed. The shorter winter storm duration is probably associated with the winter dry bias in the region. In the central U.S., PCM generates too frequent and longer lasting storms in summer, as well as overly frequent storms in winter. The higher frequency rainfall in the central U.S. likely reflects the weak onset criteria of CCM3 moist convective activity. PCM has a much stronger diurnal precipitation variation than observed, and tends to have maximum afternoon precipitation over inland area in United States. This model diurnal pattern matches observations well in the Northwest and the Northeast, but severely deviates from the nocturnal maximum rainfall pattern observed in the northern Great Plains and north central United States. Because the diurnal cycle of summer precipitation mainly reflects the diurnal variability of convective activity, PCM cannot capture the convective activity variation pattern in Northern Great Plains and north central United States.

PCM has a cold bias in annual mean temperature in most of the U.S. except in some wet regions such as the east and west coasts and some parts of the Southeast. The most severe cold bias occurs in the arid southwest and some parts of the central U.S., where the maximum difference can be $-6 \mathrm{~K}$. The strongest cold biases occur in spring, especially in the central and western area, where the deviation can be $-8 \mathrm{~K}$. A severe summer cold bias is found in central area high mountain area, which is associated with the strong deep convective process there. Autumn is the best-simulated season. PCM tends to underestimate the daily temperature range of the diurnal cycle by decreasing the daily maximum temperature and increasing the daily minimum temperature. This is particularly true in the central area, where such deviations are related to the overestimated precipitation. The high rainfall leads to higher latent heat flux and lower surface temperature.

PCM tends to have high net SW (relative to a data set derived from the daily temperature range) over most of the U.S., which is probably associated with the insufficient absorption of the shortwave radiation by the CCM clouds. In most areas, the positive deviation ranges from $20-60 \mathrm{~W} / \mathrm{m}^{2}$. The highest deviations $\left(>60 \mathrm{~W} / \mathrm{m}^{2}\right)$ are found in the west side of Rocky Mountains and in Idaho. PCM agrees well with the derived data set in the central area of the Rocky Mountains, indicative of the model's good simulation of total cloud cover there. PCM performs well in simulating the spring, summer and winter diurnal cycle of net shortwave surface flux. In autumn PCM has a pronounced noontime peak which exceeds that of the derived data set by about $5 \sim 10$ percent on average. The actual difference between PCM and observations is probably less than this difference because the derived data set likely has a slight downward bias, which is most pronounced in the estimated daily peak values. Comparison of PCM estimates of soil moisture with a data set derived from observations shows that the PCM soil moisture storage (in the upper $0.7 \mathrm{~m}$ of the soil column) is considerably less variable the values derived from observations, especially in the interior of the country. As noted above, PCM snow water equivalent (SWE) is much lower than that derived from observations (which in turn is biased somewhat downward relative to direct observations based 
on local comparisons). This strong downward bias likely results, at least in part, from the model's use of grid point mean elevations, and could be resolved relatively easily by use of an elevation band subgrid parameterization.

PCM simulates reasonably well the large-scale teleconnection patterns of ENSO and the North Pacific Oscillation (NPO), both of which are associated with wintertime climate variability over the western U.S. The ENSO response in precipitation captures the wetter conditions over the southeastern U.S. and California during warm (El Niño) events with amplitude similar to that observed. The drier conditions in the Pacific Northwest are shifted northward and underestimated, however, and the model misses the moderate ENSO response over the southwest U.S. The temperature response to the NPO captures the warmer conditions in the north-central and western parts of the U.S. along with the colder conditions in the southeast, but overestimates the amplitude of this response by a factor of two. This is likely a result of overly strong forcing; the expression of the NPO in the North Pacific, for example, where the phenomenon is centered, is about twice as strong as observed. This is partly due to greater overall variability in the model as compared to observations in the North Pacific, and partly to greater concentration of the model's variability into the NPO pattern.

\section{Acknowledgements}

The U.S. Department of Energy's Office of Science (BER) Accelerated Climate Prediction Initiative provided funding for this research, which was performed at the University of Washington under Grant No. 354967-AQO and at the Scripps Institution of Oceanography under Grant No. DE-FG03-98ER62505. This publication was also supported by the Joint Institute for the Study of the Atmosphere and Ocean (JISAO) under NOAA Cooperative Agreement No. NA67RJ0155, Contribution \#927. The assistance of Gordon Bonan, who helped clarify specifics of the PCM archived soil moisture, is appreciated. The comments of Michael Dettinger of SIO/USGS regarding the strength of the model's NPO variability are gratefully acknowledged.

\section{References}

Abdulla, F. A., Lettenmaier, D. P., Wood, E. F., and Smith, J. A.: 1996, 'Application of a Macroscale Hydrologic Model to Estimate the Water Balance of the Arkansas-Red River basin', J. Geophys. Res. 101, 7449-7459.

Barnett, T. P., Malone, R., Pennell, W., Stammer, D., Semtner, A., and Washington, W.: 2004, 'The Effects of Climate Change on Water Resources in the West: Introduction and Overview', Clim. Change 62, 1-11.

Bonan, G. B.: 1996, The NCAR Land Surface Model (LSM version 1.0) Coupled to the NCAR Community Climate Model. NCAR Tech. Note NCAR/TN-429+STR, 171 pp. [Available from NCAR, P.O. Box 3000, Boulder, CO 80307]

Bonan, G. B.: 1998, 'The Land Surface Climatology of the NCAR Land Surface Model Coupled to the NCAR Community Climate Model', J. Climate 11, 1307-1326. 
Cane, M. A., Clement, A. C., Kaplan, A., Kushnir, Y., Pozdnyakov, D., Seager, R., Zebiak, S. E., and Murtugudde, R.: 1997, 'Twentieth-Century Sea Surface Temperature Trends', Science 275, 957-960.

Cayan, D. R. and Webb, R. H.: 1992, 'El Nino/Southern Oscillation and Streamflow in the Western United States. El Nino: Historical and Paleoclimatic Aspects of the Southern Oscillation', in Diaz H. F. and Markgraf, V. (eds.), Cambridge University Press.

Changnon, S. A.: 1999, 'Impacts of 1997-98 El Nino-Generated Weather in the United States', Bull. Amer. Meteorol. Soc. 80, 1819-1827.

Christensen, N., Wood, A., Voisin, N., Lettenmaier, D., and Palmer, R.: 2004, 'Effects of Climate Change on the Hydrology and Water Resources of the Colorado River Basin', Clim. Change 62, 337-363.

Dai A., Giorgi F., and Trenberth, K. E.: 1999a, 'Observed and Model-Simulated Diurnal Cycles of Precipitation over the Contiguous United States', J. Geophys. Res. 104, 6377-6402.

Dai, A., Trenberth K. E., and Karl, T. R.: 1999b, 'Effects of Clouds, Soil Moisture, Precipitation, and Water Vapor on Diurnal Temperature Range', J. Climate 12, 2451-2473.

Dai, A., Washington, W., Meehl, G., Bettge, T., and Strand, W.: 2004, 'The ACPI Climate Change Simulations', Clim. Change 62, 29-43.

Daly, C., Neilson, R. P., and Phillips, D. L.: 1994, 'A Statistical-Topographic Model for Mapping Climatological Precipitation over Mountainous Terrain, J. Appl. Meteorol. 33, 140-158.

Da Silva, A. M., Young, C. C., and Levitus, S.: 1995, Atlas of Surface Marine Data 1994, Volume 1: Algorithms and Procedures. NOAA Atlas NESDIS 6, U.S. Dept. Commerce, 299 pp.

Deser, C. and Blackmon, M. L.: 1995, 'On the Relationship between Tropical and North Pacific Sea Surface Temperature Variations', J. Climate 8, 1677-1680.

Dukowicz, J. K. and Smith, R. D.: 1994, 'Implicit Free-Surface Method for the Bryan-Cox-Semtner Ocean Model', J. Geophys. Res. 99, 7991-8014.

Gershunov, A. and Barnett, T. P.: 1998, 'ENSO Influence on Intraseasonal Extreme Rainfall and Temperature Frequencies in the Contiguous United States: Observations and Model Results', $J$. Climate 11, 1575-1586.

Hunke, E. C. and Dukowicz, J. K.: 1997, ‘An Elastic-Viscous-Plastic Model for Sea Ice Dynamics', J. Phys. Oceanog. 27, 1849-1867.

Kiehl, J. T., Hack, J. J., Bonan, G. B., Boville, B. A., Williamson, D. L., and Rasch, P. J.: 1998, 'The National Center for Atmospheric Research Community Climate Model: CCM3', J. Climate 11, $1131-1149$.

Kiehl J. T., Hack, J. J., and Hurrel, J. W.: 1998, 'The Energy Budget of the NCAR Community Climate Model: CCM3', J. Climate 11, 1151-1178.

Kimball, J. S., Running, S. W., and Nemani, R.: 1997, 'An Improved Method for Estimating Surface Humidity from Daily Minimum Temperature', Agric. For. Meteor. 85, 87-98.

Latif, M. and Barnett, T. P.: 1994, 'Causes of Decadal Climate Variability over the North Pacific and North America', Science 266, 634-637.

Latif, M. and Barnett, T. P.: 1996, 'Decadal Climate Variability over the North Pacific and North America: Dynamics and Predictability', J. Climate 9, 2407-2423.

Liang, X., Lettenmaier, D. P., Wood, E. F., and Burges, S. J.: 1994, 'One-Dimensional Statistical Dynamic Representation of Subgrid Spatial Variability of Precipitation in the Two-Layer Variable Infiltration Capacity Model', J. Geophys. Res. 101, 21403-21422.

Lin, X, Randall, D. A., and Fowler, L. D.: 2000, 'Diurnal Variability of the Hydrologic Cycle and Radiative Fluxes: Comparisons between Observations and a GCM', J. Climate 13, 4159-4179.

Mantua, N. J., Hare, S. R., Zhang, Y., Wallace, J. M., and Francis, R. C.: 1997, 'A Pacific Interdecadal Climate Oscillation with Impacts on Salmon Production', Bull. Amer. Meteorol. Soc. 78, 10691079 . 
Maurer, E. P., Wood, A. W., Adam, J. C., Lettenmaier, D. P., and Nijssen, B.: 2002, 'A Long-Term Hydrologically-Based Data Set of Land Surface Fluxes and States for the Conterminous United States', J. Climate, accepted for publication.

Mechoso, C. R., Robertson, A. W., Barth, N., Davey, M. K., Delecluse, P., Gent, P. R., Ineson, S., Kirtman, B., and Latif, M., et al.: 1995, 'The Seasonal Cycle over the Tropical Pacific in Coupled Ocean-Atmosphere General Circulation Models', Mon. Wea. Rev. 123, 2825-2838.

Nijssen, B., Lenttenmaier, D. P., Liang, X., Wetzel, S. W., and Wood, E.: 1997, 'Streamflow Simulation for Continental-Scale River Basins', Water Resour. Res. 33, 711-724.

Nijssen, B., O’Donnel, G. M., Lenttenmaier, D. P., Lohmann, D., and Wood, E.: 2001, 'Predicting the Discharge of Global Rivers', J. Climate 14, 3307-3323.

Pan Ming, Sheffield, J., Wood, E. F., and Mitchell K. E., et al.: 2002, 'Snow Process Modeling in the North American Land Data Assimilation System (NLADS). Part II: Evaluation of Model Simulated Snow Water Equivalent', JGR, in review.

Payne, J., Wood, A., Hamlet, A., Palmer, R., and Lettenmaier, D.: 2004, 'Mitigating the Effects of Climate Change on the Water Resources of the Columbia River Basin', Clim. Change 62, 233-256.

Pierce, D. W.: 2001, 'Distinguishing Coupled Ocean-Atmosphere Interactions from Background Noise in the North Pacific', Prog. Oceanogr. 49, 331-352.

Ropelewski, C. F. and Halpert, M. S.: 1986, 'North American Precipitation and Temperature Patterns Associated with the El Nino/Southern Oscillation (ENSO)', Mon. Wea. Rev. 114, 2352-2362.

Schaake J., Duan, Q. Y., and Mitchell K., et al.: 2003, 'Analysis of Water Storage in Land Data Assimilation System (LDAS) Land Surface Models (LSMs), JGR, submitted.

Shepard D. S.: 1984, 'Computer Mapping: The SYMAP Interpolation Algorithm, in Gaile G. L. and Willmott, C. J. (eds.), Spatial Statistics and Models, D. Reidel, Norwell, Mass, pp. 133-145.

Smith, R. D., Dukowicz, J. K., and Malone, R. C.: 1992, 'Parallel Ocean General Circulation Modeling', Physica D 60, 38-61.

Thornton, P. E. and Running, S. W.: 1999, 'An Improved Algorithm for Estimating Incident Daily Solar Radiation from Measurements of Temperature, Humidity, and Precipitation', Agric. For. Meteorol. 93, 211-228.

Timmermann, A., Oberhuber, J., Bacher, A., Esch, M., Latif, M., and Roeckner, E.: 1999, 'Increased El Nino Frequency in a Climate Model Forced by Future Greenhouse Warming', Nature 398, 694-697.

Trenberth, K. E. and Shea, D. J.: 1987, 'On the Evolution of the Southern Oscillation', Mon. Wea. Rev. 115, 3078-3096.

VanRheenen, N., Wood, A., Palmer, R., and Lettenmaier, D.: 2004, 'Potential Implications of PCM Climate Change Scenarios for Sacramento-San Joaquin River Basin Hydrology and Water Resources', Clim Change 62, 257-281.

Wallace, J. M.: 1975, 'Diurnal Variations in Precipitation and Thunderstorm Frequency over the Conterminous United States', Mon. Wea. Rev. 103, 406-419.

Washington, W. M., Weatherly, J. W., Meehl, G. A., Semtner, A. J., Bettge, T. W., Craig, A. P., Strand, W. G., Arblaster, J., Wayland, V. B., James, R., and Zhang, Y.: 2000, 'Parallel Climate Model (PCM) Control and Transient Simulations', Clim. Dyn. 16, 755-774.

Zhang, G. J. and McFarlane, N. A.: 1995, 'Sensitivity of Climate Simulations to the Parameterization of Cumulus Convection in the Canadian Climate Centre General Circulation Model', AtmosOcean 33, 407-446.

Zhang, J. and Hibler, W. D.: 1997, 'On an Efficient Numerical Method for Modeling Sea Ice Dynamics', J. Geophys. Res. 102, 8691-702.

Zhang, M. H., Lin W. Y., and Kiehl, J. T.: 1998, 'Bias of Atmospheric Shortwave Absorption in the NCAR CCM: Comparison with Monthly ERBE/GEBA Measurements', J. Geophys. Res. 103, 8919-8925.

(Received 10 July 2002; in revised form 27 May 2003) 